NBER WORKING PAPER SERIES

HOW DOES CHARITABLE GIVING RESPOND TO INCENTIVES AND INCOME?
DYNAMIC PANEL ESTIMATES ACCOUNTING FOR PREDICTABLE CHANGES
IN TAXATION

\author{
Jon Bakija \\ Bradley Heim \\ Working Paper 14237 \\ http://www.nber.org/papers/w14237 \\ NATIONAL BUREAU OF ECONOMIC RESEARCH \\ 1050 Massachusetts Avenue \\ Cambridge, MA 02138 \\ August 2008
}

Thanks to Jerry Auten, Daniel Feenberg, David Joulfaian, Jim Poterba, and participants at the NBER Tax Expenditures Conference for helpful comments on this paper, and to Joel Slemrod, Jim Hines, Roger Gordon, Gary Solon, Rob McClelland, Mark Wilhelm, Bill Randolph, and seminar participants at a variety of institutions for valuable discussions on earlier incarnations of the project. The views expressed herein are those of the authors and do not necessarily reflect the views of the National Bureau of Economic Research or the U.S. Department of Treasury.

NBER working papers are circulated for discussion and comment purposes. They have not been peerreviewed or been subject to the review by the NBER Board of Directors that accompanies official NBER publications.

(C) 2008 by Jon Bakija and Bradley Heim. All rights reserved. Short sections of text, not to exceed two paragraphs, may be quoted without explicit permission provided that full credit, including @ notice, is given to the source. 
How Does Charitable Giving Respond to Incentives and Income? Dynamic Panel Estimates Accounting for Predictable Changes in Taxation

Jon Bakija and Bradley Heim

NBER Working Paper No. 14237

August 2008

JEL No. D12,D91,H2,H24,H31

\begin{abstract}
We estimate the elasticity of charitable giving with respect to its price and after-tax income using a panel of over 550,000 disproportionately high-income tax returns spanning the years 1979 through 2005. Improvements relative to the previous literature include: using state tax variation to help identify our model while controlling for both individual- and time-specific unobserved heterogeneity; carefully dealing with expectations; allowing people at different income levels to have different degrees responsiveness to taxation and different time paths of unobservable influences on giving; and using a measure of charitable giving that more closely approximates current donations. To address the omitted variable bias that would otherwise arise from failing to control for unobservable expectations of future prices and future incomes, we use predictable changes in future federal and state marginal tax rates and tax liabilities, arising from their pre-announced and phased-in nature, as instruments for future changes in prices and income. Our estimate of the elasticity of giving with respect to a persistent price change for the full sample is about -0.7 ; this elasticity is generally larger when the sample is limited to high-income people and we control for time-varying unobservable influences on charity in a flexible fashion. We find some evidence, particularly among very high-income people, of re-timing giving in response to expected future changes in price, but this finding is sensitive to the source of identification for the price effects. Our estimates are broadly consistent the permanent income hypothesis. Expenditures on charitable giving are estimated to respond more strongly to persistent changes in income than to transitory fluctuations in income. Moreover, we find evidence in some specifications that people will increase their charitable giving now in response to a predictable reduction in future tax liability arising from tax reform.
\end{abstract}

Jon Bakija

Economics Department

Williams College

Williamstown, MA 01267

Jon.M.Bakija@williams.edu

Bradley Heim

Department of the Treasury

Room 4036B

1500 Pennsylvania Ave NW

Washington, DC 20220

Bradley.Heim@do.treas.gov 
Income taxation policies in the United States provide a substantial price subsidy for charitable donations, and the degree to which people respond to this subsidy is a matter of considerable policy interest. The federal income tax and most state income taxes allow a deduction for charitable contributions, which effectively reduces the price of those contributions relative to non-deductible consumption to one minus the marginal income tax rate for those who itemize deductions. The opportunity to avoid capital gains taxes on charitable gifts of appreciated assets reduces the price of charity still further. Income tax reform proposals often involve changes to the treatment of charity. For instance, the 2005 report of the President's Advisory Panel on Federal Tax Reform proposed extending a tax benefit for charity to all taxpayers, but limiting it to charitable donations that exceeded one percent of income. In general, the case for providing tax incentives for charitable giving is stronger when charitable giving decisions are more responsive to the incentives. Saez (2004) demonstrates this intuition in a formal optimal tax model where charitable donations are treated as a consumption good with positive externalities. In that case, the economically efficient subsidy rate for charity is higher when donations are more responsive to their price. We are also interested in separately identifying the elasticity of charitable giving with respect to after-tax income, as this too is useful for policy evaluation, and it is necessary if we want to know the independent effect of price.

There have been many empirical estimates of the elasticity of charitable giving with respect to its price and to after-tax income. Peloza and Steele (2005) and Brown (1996) offer recent literature reviews. This literature has run up against several critical econometric challenges that we will address in our paper. These include: separately identifying price and income effects when the true functional form of the demand equation for charity is unknown; distinguishing transitory changes in price and income from persistent changes and disentangling the responses to each; controlling for various types of unobservable influences on charitable giving behavior that may be correlated with prices and incomes; and allowing for parameter heterogeneity across individuals. 
Early literature on charitable giving and taxation relied on single-year crosssectional income tax return data, and typically regressed log of charitable deductions on $\log$ price, log after-tax income, and a limited set of control variables available in the tax return data. Clotfelter (1985) reports a price elasticity of -1.2 and an income elasticity of 0.7 as typical of estimates from these studies, suggesting that charitable giving was indeed very responsive to incentives. In a cross section, variation in price arises largely because the marginal federal income tax rate is an increasing non-linear function of income. Feenberg (1987) pointed out that in that case, separate identification of price and income effects relies almost entirely on restrictive assumptions about the functional form of the demand equation for charity. Price elasticity estimates could be biased, for example, if income has some arbitrary non-linear relationship with charitable giving but the appropriate non-linear functions of income are omitted from the specification, or if there are omitted variables that influence charitable giving and that have a non-linear relationship with income. ${ }^{1}$

Numerous subsequent studies of charitable giving have exploited panel data. With panel data, the researcher can use a fixed effects approach to control time-invariant characteristics of taxpayers that influence charity, that may be correlated with the explanatory variables, and that are not observed in the data. Examples when using tax data might include, among other things, religiosity, education, and alumni ties. Year dummies can also be used to control for any unobservable factors that influence charitable giving in the same way for everyone in the sample over time. When panel studies have controlled for fixed effects and years dummies, the identification for price effects has come largely from the fact that federal tax reforms changed marginal income tax rates in different ways over time for different people. To the extent that this variation is independent of income, it helps reduce the problem emphasized by Feenberg.

\footnotetext{
${ }^{1}$ Feenberg addresses this problem in cross-sectional data by using instruments for price where all the variation comes from differences in state tax laws, and he still finds the price elasticity to be large. Identification problems nonetheless remain a concern.
} 
Another key question is how to disentangle long-run responses to persistent changes in price and income from short-run timing behavior. The optimal degree of subsidy to charity depends largely on the degree to which subsidizing it will increase the long-run level of giving. Knowing the degree to which people are willing to re-time giving in response to temporal variation in incentives would also be useful for evaluating certain types of reforms, such as disallowing deductions for contributions that are below a certain percentage of income, which creates an incentive to bunch giving into alternate years. Distinguishing between long-run and timing behavior is difficult but important. For example, if we find that people give more to charity when they face high tax rates, that might mean the tax incentive is effective in promoting longrun giving, or it might mean that people are moving charitable giving into that year from other years with lower tax rates, possibly without changing the long-run amount of giving at all.

Transitory variation in price can arise because of a temporary fluctuation in income that pushes the taxpayer into a different tax bracket, or because of changes in tax law. There are often long lags between proposal and enactment of changes in tax law, and once enacted, the changes may not begin to apply until a future year, and may be gradually phased-in over several years. As a consequence, differences between current and expected future prices of charitable giving are ubiquitous, creating many opportunities to reduce tax liability through re-timing of giving. We might expect timing behavior to be much more responsive to incentives than long-run behavior, because changing the timing of giving may involve little or no real sacrifice, whereas changing the long-run level of giving requires a real sacrifice of lifetime consumption. In principle, though, it could go the other way around. For instance, people might respond more to a persistent change in prices than to a short-run transitory change, because it takes a while to learn about the changes in incentives or to change old habits and commitments.

Transitory fluctuations in pre-tax income and predictable changes in tax law also create differences between current and expected future after-tax incomes. Milton 
Friedman's (1957) permanent income hypothesis suggests that consumption expenditures should respond more to persistent variation in income than to transitory variation, but if we fail to distinguish empirically between them, then we estimate a mix of the two responses, which may be inadequate for policy evaluation, and it may cause biased estimates of the price effects as well. These problems are made all the more difficult because expectations of future prices and income are fundamentally unobservable. Actual realizations of future prices and incomes are measurements with error of current expectations of those variables, so a solution that assumed perfect foresight and included actual realizations of the future variables in the specification would suffer form errors-in-variables bias, which typically biases coefficients on those variables towards zero.

Studies of charitable giving using panel data have addressed these empirical challenges in a variety of ways, but solutions implemented so far have not led to consensus on the magnitudes of the relevant elasticities. Randolph (1994) uses an individual's ten-year average income, interacted with dummies for time periods corresponding to different federal tax regimes, as instruments for the current federal tax price and current disposable income, in an effort to isolate the permanent portion of variation in current price and income. He then uses the residual between current price and income and their values predicted by the permanent instruments as measures of transitory fluctuations in price and income. Randolph estimates very large responses to transitory price variation and small responses to persistent price variation. When evaluated at the mean expenditure share of giving in his sample, the transitory price elasticity is found to be -2.3 , while the persistent price elasticity is just - 0.1 . Randolph's evidence does suggest that timing behavior could be quite important and that failure to take it into account could seriously bias estimates of the persistent effect of price, but it leaves open a number of questions. Because the identification strategy relies heavily on differences across people in ten-year averages of income, he is unable to control for unobserved heterogeneity through fixed effects, and the estimates are also potentially quite sensitive to the identification problems highlighted by Feenberg, because much of 
the identifying price variation comes from cross-sectional differences in income. Another issue is that the difference between current and ten-year average income is assumed to be all transitory, when in fact some of it may reflect innovations in permanent income over time. The procedure also offers no way to deal with preannounced or anticipated changes in tax law, and instead omits years, like 1986, when tax reforms created obvious differences between current tax rates and the tax rates that people knew would apply in the future. This fails to exploit a particularly credible way to identify differences between current and expected future prices, and whether people respond to these differences. Moreover, the whole idea of re-timing giving implies that behavior in the years with differences between current and expected future taxes has consequences for the level of giving in other years, so omitting the years with transitory differences does not necessarily solve the problem.

Auten, Sieg, and Clotfelter (2002) estimate a system where income and price are assumed to follow a stochastic process where each experiences random-walk style shocks that persist indefinitely, along with random transitory shocks that die off after one year. Their estimates vary depending on specification, but for the most part suggest a large elasticity of giving with respect to persistent price changes and a small elasticity with respect to transitory price changes. The procedure that they develop deals well with transitory fluctuations of the sort where, for example, income or price goes up for one year and then goes back down. It does not deal well with situations where one persistent pattern of prices suddenly changes to another persistent pattern of prices, but where people anticipate the change and respond to it in advance, because their estimation procedure treats the actual persistent change in tax rates as a surprise at the date it starts to apply. If people accelerate or delay giving in anticipation of the future persistent change, that can contaminate their estimates of the response to the persistent change, which is based on comparing giving before and after the change assuming it was a surprise. The major federal tax reforms during their sample period were generally predictable before the year they began to apply, so this is potentially an important concern. 
Several papers, including Broman (1989), Barrett, McGuirk, and Steinberg (1997), Bakija (2000), and Bakija and McClelland (2004), among others, have used panel data to estimate models of charitable giving that control in various ways for predictable future changes in tax law, as have a variety of papers looking at the effects of taxes on other forms of behavior where timing may be important, such as capital gains realizations and taxable income elasticities. We build on these approaches. The charity papers mentioned above estimated relatively small persistent price elasticities and somewhat larger transitory price elasticities, but with wide confidence intervals. These studies all used a small public-use panel of individual tax returns with very few high income taxpayers. So part of the motivation of this paper is to deal carefully with anticipated changes in tax law using better data.

All prior panel studies on charitable giving involve some restrictive identifying assumptions that we wish to relax in this paper. They effectively use middle income people (for whom federal tax reforms had little impact on marginal tax rates) as a control group for high income people (for whom federal tax reforms had large impacts on marginal rates). This may be a source of bias because patterns of giving over time for middle-class people may provide an inaccurate counterfactual for what would have happened to the charitable giving of high-income people in the absence of tax changes. Moreover, responsiveness to tax incentives may differ systematically across income groups, but previous studies have not typically had a credible source of identification to allow separate estimates of price elasticities at different income levels. We exploit state income tax variation to provide us with identification that is sufficiently strong to

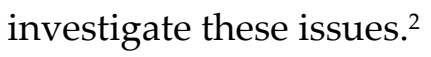

2 Karlan and List (2007) study individuals who had previously contributed to a non-profit organization and were randomly selected to receive different matching rates on their contributions to that organization in a mail solicitation. They find that offering a match increases donations relative to not offering a match, but that once a match is offered, varying the size of the match has no statistically significant effect on the amount of contributions. Their estimates imply an absolute price elasticity of giving of 0.3 when evaluated over the full sample. Among people who receive any match at all, the implied price elasticity of giving is approximately zero. Although extrapolating from their setting to tax policy would raise some questions of external validity, Karlan and List's experimental evidence does intensify the concerns about potential 
We use a large panel of tax returns that spans 1979-96 and 1999-2005 and heavily oversamples high-income people to estimate the responsiveness of charitable giving to price and after-tax income. To distinguish transitory from persistent variation in prices and incomes, we include lagged and future changes in price and income in the specification. We estimate models that use predictable changes in federal and state tax law as instruments for future changes in prices and income, and we show that this makes a difference relative to assuming perfect foresight, particularly for the estimated income elasticities. To allow for parameter heterogeneity across people in different income classes, we then estimate our model on subsets of the sample segregated by income, and we use a variety of methods to control for the possibility of unobservable influences on charity that are changing over time. Our estimate of the elasticity of giving with respect to a persistent price change for the full sample is about -0.7 ; this elasticity is generally larger when the sample is limited to high-income people and we control for time-varying unobservable influences on charity in a flexible fashion. We find some evidence, particularly among very high-income people, of re-timing of giving in response to expected future changes in price, but this finding is sensitive to the source of identification for the price effects. Our estimates are broadly consistent with the permanent income hypothesis. Expenditures on charitable giving are estimated to respond more strongly to persistent changes in income than to transitory fluctuations in income. Moreover, we find evidence in some specifications that people will increase their charitable giving now in response to a predictable reduction in future tax liability arising from tax reform.

problems in studies using observational data. By exploiting state tax variation and relaxing various identifying restrictions imposed in the previous literature, we provide estimates that are more robust to the kinds of problems that might otherwise explain the differences between observational and experimental estimates. 


\section{Empirical model}

Following most of the previous literature, we estimate a log-log demand equation for charitable giving. In log-log models, the price elasticity and income elasticity are restricted to be constant across all observations in the sample used for estimation, and can be determined directly from the coefficients. We later relax the assumption of constant elasticities by estimating the model on sub-samples of our data segregated by income. Our primary specification, shown in equation (1) below, modifies the traditional log-log specification in a variety of ways in order to address various empirical challenges.

$$
\begin{aligned}
& \ln (\text { charity })_{\mathrm{it}}=\alpha_{\mathrm{i}}+\alpha_{\mathrm{t}}+\mathbf{X}_{\mathrm{it}} \beta_{0} \\
& +\beta_{1} \Delta \ln P_{\mathrm{it}-1}+\beta_{2} \Delta \ln P_{\mathrm{it}}+\beta_{3} \ln \mathrm{P}_{\mathrm{it}}+\beta_{4} \Delta \ln P_{\mathrm{i}, \text { future }} \\
& +\beta_{5} \Delta \ln Y_{\mathrm{it}-1}+\beta_{6} \Delta \ln Y_{\mathrm{it}}+\beta_{7} \ln Y_{\mathrm{it}}+\beta_{8} \Delta \ln Y_{\mathrm{i}, \text { future }} \\
& +\varepsilon_{\mathrm{it} .}
\end{aligned}
$$

In equation (1), $i$ indexes individuals and $t$ indexes years. The dependent variable $\ln ($ charity) it is the $\log$ of charitable donations (plus $\$ 100$, to deal with the very small portion of the sample with $\$ 0$ of reported donations). To control for unobserved heterogeneity, we include fixed effects $\left(\alpha_{\mathrm{i}}\right)$ for each unique taxpaying unit. ${ }^{3}$ We control for any influences on charity that change in the same way over time for everyone through year effects $\left(\alpha_{\mathrm{t}}\right)$. The vector $\mathbf{X}$ is a set of control variables that will be explained further below, and $\varepsilon_{\text {it }}$ is an error term. The primary variables of interest are the log of the price of charitable giving $(\ln P)$, the log of after-tax income $(\ln Y)$, and lagged and future changes in each of those variables. The $\Delta$ variables with time subscripts represent first-differences of those variables (e.g., $\left.\Delta \ln P_{\mathrm{it}-1}=\ln P_{\mathrm{i} t-1}-\ln P_{\mathrm{it}-2}\right)$. The $\Delta \ln P_{\mathrm{i}, \text { future }}$ and $\Delta \ln Y_{\mathrm{i}, \text { future }}$ variables represent future values of price and income minus their current year

\footnotetext{
${ }^{3}$ A unique taxpaying unit is defined here as a primary taxpayer, and if married his or her spouse, during a span of time when there is no change in marital status on that taxpayer's returns.
} 
$t$ values. For these future changes in price and income, in different specifications, we try using the change over the next two years (that is, the $t+2$ values of $\ln P$ and $\ln Y$ minus their year $t$ values), and the change over the next one year (that is, the $t+1$ values of $\ln P$ and $\ln Y$ minus their year $t$ values). The use of two-year future changes is motivated by the fact that many pre-announced tax reforms are gradually phased in over multiple future years. ${ }^{4}$

In equation (1), the effect on long-run giving of a persistent increase in price is given by $\beta_{3}$. Intuitively, $\beta_{3}$ estimates the effect of a one percent increase in price holding two lagged changes in price and the future change in price constant, which happens when there has been an increase in price that has persisted over three years and is expected to persist into the future as well. ${ }^{5}$ The effect on giving today of an anticipated future increase in price is given by $\beta$. The effect on giving today of a transitory increase in price this year that is expected to disappear in the future is given by $\left(\beta_{2}+\beta_{3}-\beta_{4}\right)$. Intuitively, $\beta_{3}$ tells us the effect on giving this year of the price this year per se, while $\beta_{2}$ and $\beta_{4}$ tell us the effect on giving today of the price today being different from last year and future years. Analogously, $\beta_{7}$ is the response to a persistent increase in income, $\beta 8$ is the response to an anticipated increase in future income, and the effect on giving today of a transitory increase in income that goes away in the future is given by $\left(\beta_{6}+\beta_{7}-\right.$ $\beta 8)$.

The price of charitable giving, $P_{\mathrm{it}}$, is defined as:

\footnotetext{
${ }^{4}$ We also experimented with including the changes in price and income from $t$ to $t+1$ and the changes from $t+1$ to $t+2$ separately in the same specification, but we found that predictable changes in future tax law did not provide sufficient variation to distinguish the effects of the oneperiod ahead and two-period ahead changes from each other (as opposed to the combined effect of both future changes taken together, which we can identify).

${ }^{5}$ Note that equation (1) above can be re-arranged so that the price variables and their coefficients enter as $\gamma_{1} \ln P_{i t-2}+\gamma_{2} \ln P_{i t-1}+\gamma_{3} \ln P_{i t}+\gamma_{4} \ln P_{i, f u t u r e} . \beta_{3}$ from equation (1) is equivalent $\gamma_{1}+\gamma_{2}+\gamma_{3}+\gamma_{4}$ in that alternative specification, so $\beta_{3}$ estimates the effect of a uniform percentage increase in price that has already persisted for three years and is expected to persist into the future. An analogous re-arrangement can be performed with the income variables.
} 


$$
P_{i t}=1-m \operatorname{tr}_{i t}-n_{i t}^{*} a^{*}\left(d^{*} m \operatorname{trcg} g_{i+1}-m \operatorname{trcharcg} g_{i t}\right)
$$

This price incorporates both the tax savings from the charitable deduction, and the extra tax savings from avoiding a taxable realization of capital gains. In it, $m t r_{\text {it }}$ is the combined federal-state marginal tax rate on charitable giving (defined as the reduction in tax liability caused by a $\$ 1$ increase in charitable gift), $m t r c g^{i t+1}$ is the marginal tax rate on long-term capital gains, and mtrcharcg $g_{i t}$ is the marginal tax rate on unrealized capital gains on donations of appreciated property, which were included in the base of the federal alternative minimum tax (AMT) from 1987 through 1992 (this is non-zero only for returns subject to the AMT). ${ }^{6}$ The $n_{i t}$ represents the actual value of non-cash donations as a share of total charitable donations for the taxpaying unit in year $t .^{7}$ The $a$ represents the gain-to-value ratio for non-cash donations, and $d$ is a discount factor to reflect the fact that the alternative to donating an appreciated asset may be to hold on to it and not realize the gain until many years in the future, reducing the present value of tax liability, or perhaps to hold onto it until death, in which case it will not be taxed at all. We have estimated $a$ to be 0.65 , on average, based on AMT returns from 1989-1992. ${ }^{8}$ For $d$, we choose a value of 0.7 , based on our extrapolations from an empirical study of

\footnotetext{
${ }^{6}$ A number of states operated alternative minimum taxes based on the federal version during this period and also included gains on donations of appreciated assets in the AMT taxable base; most stopped in 1992 along with the federal, but California continued to tax these gains through 2001. We take this into account.

${ }^{7}$ Constructing $n_{i t}$ is complicated by the fact that various types of charitable contributions are subject to percentage of AGI limits, and donations in excess of those limits may be carried forward to later years. In our tax return data, the only charity variables that we have on a consistent basis are total charitable deductions after limitations, reported non-cash donations (taxpayers sometimes report amounts in excess of the limits for these), and carryovers from prior years that are deducted in the current year. The data do not indicate whether carried over amounts were originally cash or non-cash. Given this, we define $n_{\text {it }}$ to be the minimum of noncash donations currently reported by the taxpayer or 30 percent of AGI (the limit applicable for most types of non-cash donations), divided by the current charitable deduction after limitations less carryovers from prior years.
}

${ }^{8}$ To avoid sample selection bias, we computed this mean using only returns that would have been subject to the AMT even if they had not donated any appreciated assets. 
the distribution of the timing of asset sales conducted by Ivkovic, Poterba, and Weisbenner (2005). ${ }^{9}$ This discount factor $d$ only applies to $m t r c g$, because if a taxpayer donates a dollar of an appreciated asset, they must pay mtrcharcg today. We use the anticipated future $m \operatorname{trc} g_{i t+1}$ because the likely alternative to current donation of an appreciated asset is realization of the capital gain at some point in the future.

Current price is endogenously related to current charitable giving, because a large charitable deduction can push the taxpayer into a different tax bracket. Past and future prices may also be endogenously related to current giving because charitable giving may be serially correlated across time. To address this, we construct "first-dollar" instruments for all the price variables that re-compute the prices setting charity to zero, a common practice in the literature. ${ }^{10}$ We also follow the previous literature by treating $n_{i t}$ as endogenous. For example, gifts of appreciated assets tend to be large and lumpy, so $n_{i t}$ may be particularly large in years when large gifts are made. Therefore, in the instruments for price variables we replace $n_{i t}$ with an exogenous value, the average value of $n$ in our sample, $0.16 .{ }^{11}$

${ }^{9}$ Further details on how we derive our value for $d$ are provided in an appendix. Previous literature has ignored mtrcharcg and thus only needed to assume a value for the product of $a$ and $d$. Most commonly, that product is assumed to be 0.5 , based on maximum likelihood estimates reported in Feldstein (1975) and Feldstein and Clotfelter (1976). Our value for that product, $0.65^{*} 0.7=0.455$, is thus quite similar to what was assumed in the previous literature.

${ }^{10}$ When computing price instruments and first-dollar tax liability, we also set to zero a class of miscellaneous alternative minimum tax preferences (including things like accelerated depreciation, but not the more common preferences such as itemized deductions). This is necessary because this class of AMT preferences includes unrealized capital gains on donations of appreciated assets in some years, and the data do not always enable us to separate this out.

${ }^{11}$ Randolph and Auten, Sieg, and Clotfelter use income-class and year-specific mean values of $n$ to construct their instruments. We use the sample mean of $n$ because for our sample as a whole, because we did not find much variation across income classes in the average value of $n$ (although there was a positive correlation in the early years of the sample), and because year-to-year variation in $n$ appears to be contaminated by endogenous responses to timing incentives (for instance, $n$ was unusually large in 1986, apparently in anticipation of how TRA86 would change incentives in the future). 
$Y_{i t}$ is after-tax income, and is defined as pre-tax income less federal and state income tax liability computed setting charitable giving to zero. This is standard in the literature. Intuitively, we are treating after-tax income computed setting charitable giving to zero as the available budget, and incorporating the benefits of tax deductibility of charitable giving into its price rather than after-tax income. ${ }^{12}$

The control variable vector $\mathbf{X}$ includes life cycle and demographic factors including age squared, number of children living at home, and number of other dependents. Because we will rely on state income tax variation for some of our identification, we also control for some state characteristics that could in principle affect charitable giving and might be correlated with state income tax policy. We include a variable $\ln P \_s a l e s t a x=\ln (1 /(1+s))$, where $s$ is the state retail sales tax, to control for the effect of state retail sales tax on the relative price of charitable giving. A state-year specific log of median housing price variable is included, which could have positive or negative effects on charitable giving since it is an indicator of geographic variation in both the cost of living and the value of housing wealth. We also include the state unemployment rate for each year to capture the possible impact of economic factors that may change in different ways over time in different states. We include state and local government spending as a share of personal income, to control for the possibility that public provision of public goods "crowds out" private contributions. In sensitivity analyses that omit fixed effects, we also include marital status, age, and a time-invariant survey-based measure of church attendance in each state from 2006; these are omitted

\footnotetext{
${ }_{12}$ Our measure of pre-tax income is defined to be as consistent as possible over time and across individuals given information available in our tax return data. Income equals: adjusted gross income (AGI) + (total adjustments) + (excluded capital gains) + (excluded dividends) - (social security in AGI) + (unemployment benefits excluded from AGI) - (1/2 of self-employment taxes) (state tax refunds) + (partnership and S-corporation losses). Following previous studies on this subject, we remove social security benefits from income, because information on social security benefits is not available for taxpayers with incomes below the threshold where they become taxable, and are not available at all before 1984. We add back in partnership and S-corporation losses because these largely represent passive losses (frequently related to tax shelters) that were disallowed following the Tax Reform Act of 1986, and that arguably misrepresented true economic losses before 1986.
} 
from the fixed effects specification because they are perfectly collinear with the fixed effects or the combination of fixed effects and year dummies (so we are effectively already controlling for them). ${ }^{13}$

We estimate equation (1) by two-stage least squares. Realized future changes in price and income are just measurements with error of taxpayers' expectations of those variables at time $t$, and it is the expectations that should matter for behavior at time $t$. To deal with this, we implement what we call a "predictable tax change instrument" strategy. We construct instruments for future changes in price and income where the instruments do not assume knowledge of anything that could not be known at time $t$, and where identification comes from predictable changes in taxation. For the future tax law expected as of year $t$, we assume that taxpayers know about any federal tax reform that has already been enacted in year $t$, and also know about any reform that will take effect starting in year $t+1$. So for example, we assume that taxpayers in 1986 know about TRA86 because it was enacted before the end of the year, and they knew what affect it will have in 1987 and 1988. However, we assume that people did not anticipate TRA86 in 1985. This rule also means that we assume that people in 1992 already know about the federal tax changes enacted in 1993, and in 2002 already know about the federal tax changes that would be enacted in 2003. For state tax reforms, we assume that people know about any changes in state tax parameters that will begin to apply next year, but do not know about changes that begin to apply two years or more in the future.

We use other exogenous control variables from equation (1) that are known at time $t$ to help us construct precise instruments for the future changes in price and income, but we do it in such a way that all of the independent identification for our instruments for future changes in price and income still comes from taxation. We first construct a predicted value for future pre-tax income one year or two years hence, for

\footnotetext{
${ }^{13}$ Marital status is time-invariant for an individual given our sample selection method, described below. Further details on the control variables and their sources are available in an appendix. The church attendance variable is missing for Alaska and Hawaii, so we use the national average of the variable for those two states.
} 
each individual in each year, based on a regression using the full sample. The dependent variable in that regression is the actual change in future log real pre-tax income over the next one or two years, and the explanatory variables are a subset of the exogenous explanatory variables in equation (1), including among other things current log income, two lagged changes in log income, age, and age squared. ${ }^{14}$ We then calculate predicted future marginal tax rates and tax liabilities by applying the predictable future federal and state tax laws to the predicted future pre-tax income. ${ }^{15}$ The instrument for future change in log price is then the log price computed by applying predictable future tax law to the prediction of future income, minus the current actual first-dollar log price. The instrument for future change in $\ln Y$ is predicted future $\log$ after-tax income (that is, the log of future pre-tax income predicted from the regression, less tax liability computed on that pre-tax income using predictable future tax law and setting charity to zero), minus current log after-tax income. These constructed

\footnotetext{
${ }^{14}$ The full set of explanatory variables in these regressions include current income, the two lagged changes in income, age, age squared, marital status, number of children, number of other dependents, and state unemployment rate, and an overall constant, all of which are either included as exogenous explanatory variables in equation (1), or are effectively controlled for in equation (1) through the combination of fixed effects and year dummies. The one slight modification to this is that we use current and lagged values of pre-tax income in the equations to predict future pre-tax income. We do not include year dummies or fixed effects in the regressions used to estimate this predicted future change in income, because doing so would presume perfect foresight about mean income for the individual and about the mean change in future income for the sample as a whole.

${ }^{15}$ To calculate the future marginal tax rate and future tax liability, one must know not only the future tax law and the future value of pre-tax income, but also the values of the vector $\mathbf{Z}$ of inputs to the tax calculator function such as components of income and deductions. To impute the future values of each of the dollar-valued components of $\mathbf{Z}$, we multiply predicted future pre-tax income by the average ratio of that component of $\mathbf{Z}$ to pre-tax income for that individual over the previous three years $(t-2, t-1$, and $t)$. So for instance, if long-term capital gains realizations were $10 \%$ of pre-tax income for the individual, on average, in the past three years, we set long-term capital gains realizations to $10 \%$ of predicted future pre-tax income when we calculate the future tax rates and tax liabilities used to construct our instruments. We also assume that age of taxpayer and spouse are known in advance with certainty, that changes in the number of children and the number of other dependents are known one year in advance, and that marital status is not expected to change (since our sample selection criteria exclude people with changes in marital status).
} 
instruments are then used as excluded instruments in the first stage equation of twostage least squares, in the conventional manner.

The predicted change in future log pre-tax income does not by itself add anything to the identification of our model, because it is just a linear function of other exogenous variables that we are already controlling for in our specification. This is appropriate, because explanatory variables used to construct predicted future pre-tax income are likely to have direct effects on charitable giving, so they are not valid as excluded instruments. Independent identifying variation in our instruments for future changes in price and income comes from two sources in this framework. The first is that near-future changes in federal and state tax parameters are generally predictable because of their pre-announced or phased-in nature. The predicted change in pre-tax income is merely helping us evaluate the expected impact of these anticipated changes in tax parameters for the individual. Second, although our predicted changes in pre-tax income are just linear functions of the other exogenous explanatory variables, future changes in marginal income tax rates and changes in income tax liability are complicated non-linear functions of the expected changes in pre-tax income, and those nonlinear tax functions vary greatly across time, states, and income levels. ${ }^{16}$

The instruments described so far above exactly identify the 2SLS model; there is one instrument each for $\Delta \ln P_{\mathrm{it}-1}, \Delta \ln P_{\mathrm{it}}, \ln \mathrm{P}_{\mathrm{it}}, \Delta \ln P_{\mathrm{i}, \text { future, }}$ and $\Delta \ln Y_{\mathrm{i}, \text { future. }}$. We also use two other excluded instruments in the first stage in an effort to help distinguish transitory from permanent variation in price and income. The additional instruments are the year $t$ combined federal-state marginal tax rate on long-term capital gains for the individual,

\footnotetext{
${ }_{16}$ We also experimented with constructing the future changes in price and income holding pretax income and all other inputs to the tax calculator constant in real terms at their year $t$ values. This led to broadly similar but less precise parameter estimates. In our sample, the simple correlation between pre-tax income at $t+2$ predicted using the procedure outlined above and actual pre-tax income at time $t+2$ is 0.634 . The correlation between actual pre-tax income at time $t$ and actual pre-tax income at time $t+2$ in our sample is only 0.463 . Given our demanding identification strategies, it is important for us to use all of the exogenous information at our disposal that is knowable at time $t$ to construct our instruments, in order to avoid weak instrument problems.
} 
and the year $t+1$ minus year $t$ difference in the marginal tax rate on long-term capital gains. There is strong evidence that anticipated temporal variation in capital gains tax rates causes transitory fluctuations in realized income. For instance, there was a very dramatic spike in capital gains realizations in 1986, in anticipation of an increase in the tax rate on gains that would begin to take effect in 1987 (Burman, Clausing, and O'Hare 1994). We may expect that an increase in income, and the associated decrease in price, in a year like 1986 is especially likely to be transitory, and putting the capital gains tax rate variables in the first stage excluded instrument set helps account for that. The capital gains tax rates should affect current charitable giving only through their effects on the price of giving and income, in which case it is valid to exclude them from the second stage regression. ${ }^{17}$

To demonstrate that different methods of modeling expectations make a difference, we also present some estimates that assume that taxpayers have perfect foresight. In that case, the instruments for the future changes in price and income are just the future changes in the first-dollar versions of those variables, computed using the actual future values of income, actual future tax law, and actual future values of the vector of all other inputs into the tax calculator function. ${ }^{18}$

To examine whether price and income effects differ by income class, we estimate analogs of equation (1) above on separate samples split by income categories. Each taxpaying unit is classified into an income category based on the average real income of the taxpaying unit over the years it is included in the sample. Doing so allows elasticities to differ for people at different income levels. In the specifications where we split the sample by income classes, we try three different approaches to controlling for

\footnotetext{
17 The capital gains marginal tax rate instruments are constructed in a manner analogous to the other "predictable tax change" instruments, and are computed setting charity to zero. We calculate the future change in capital gains tax rate instrument by applying the predictable future tax law to predicted pre-tax income derived from the regression described above. We also tried omitting the capital gains tax rate variables from the first stage equation. When we did that, parameter estimates were largely similar but with larger standard errors.

${ }^{18}$ We do not use the capital gains tax rate instruments in the specifications that assume perfect foresight.
} 
unobservable influences on charity that are changing over time, which we will explain further when we present the estimates.

In all specifications, we compute robust standard errors that are clustered by state and average income group, to allow for arbitrary forms of correlation among the errors in each income group / state cluster, and to allow arbitrary forms of heteroskedasticity across the clusters. ${ }^{19}$

\section{Data}

Data for this paper come from three panels of tax returns that were collected between 1979 and 2005, each of which heavily over-sampled high income taxpayers. This is useful because high-income people experienced the most interesting variation in tax incentives during this time, and because they account for a disproportionately large share of charitable giving. For example, in 2004 taxpayers with incomes above \$200,000 accounted for 36 percent of charity deducted by taxpayers, and about 30 percent of all charitable gifts by living individuals..$^{20}$

The first panel was collected from returns filed for tax years 1979 through 1995. To create this dataset, a stratified random sample (where the probability of being selected increased with income) of approximately 20,000 tax returns was drawn in 1981 . Returns from these taxpayers were then collected from 1979 and 1980, and the taxpayers were followed until 1995. Although the smallest of the three panels used, this panel covers two important tax changes for studying the responsiveness to charitable giving,

19 See Bertrand, Duflo, and Mullainathan (2004). We implement our econometric specification using xtivreg2 in Stata (Schaffer, 2007). The clustering procedure requires that an individual taxpaying unit stay in the same cluster over time, so we assign each taxpaying unit to a cluster based on the state it resided in for the largest number of years. The classes of average income used to define the clusters are: less than $\$ 50,000 ; \$ 50,000$ - $\$ 100,000 ; \$ 100,000$ to $\$ 200,000 ; \$ 200,000$ to $\$ 500,000 ; \$ 500,000$ to $\$ 1$ million; and $\$ 1$ million and above.

${ }^{20}$ Source: author's calculations based on data from the IRS web site <http://www.irs.gov/pub/irssoi/04in54cm.xls> and from the Center on Philanthropy at Indiana University (2007). 
the Economic Recovery Tax Act of 1981 (ERTA81) and the Tax Reform Act of 1986 (TRA86). Over the years 1979-1995, this panel consists of almost 290,000 returns. ${ }^{21}$

The second panel was collected from 1987 through 1996, and is known as the Family Panel..$^{22}$ This panel consists of two segments - a cohort segment that was created by drawing a stratified random sample of taxpayers (including spouses and dependents) who filed in tax year 1987 and following them over the next nine years, and a refreshment segment consisting of a random sample of taxpayers who filed in tax years 1988 through 1996 who were not filers in 1987. Overall, the Family Panel consists of 1.26 million returns, and spans the Ominibus Budget Reconciliation Acts of 1990 and 1993 (OBRA90 and OBRA93) as well as covering the end of the phase-in of TRA86.

The third panel was collected from 1999 through 2005, and is known as the Edited Panel. ${ }^{23}$ This panel consists of a stratified random sample of tax returns drawn in 1999, for which the primary and secondary filers were followed over the subsequent six years. This panel consists of more than 550,000 tax returns, and spans the two most recent major tax changes, the Economic Growth and Tax Relief Reconciliation Act (EGTRRA2001) and the Jobs and Growth Tax Relief Reconciliation Act of 2003 (JGTRRA2003).

Marginal tax rates and tax liabilities in this study were calculated using the comprehensive income tax calculator program described in Bakija (2008), and include both state and federal income taxes. The calculator incorporates such details as the minimum and alternative minimum taxes, maximum tax on personal service income, and income averaging in the years when these were applicable. ${ }^{24}$ Marginal tax rates

\footnotetext{
${ }^{21}$ Versions of this dataset have been used in previous examinations of the effect of taxes on charitable giving, including Randolph (1995) and Auten et al. (2002).

${ }^{22}$ For more information on Treasury's Family Panel, see Cilke et al. $(1999,2000)$.

${ }^{23}$ For more information on the 1999-2005 Edited Panel, see Weber and Bryant (2005).

${ }^{24}$ For some returns in 1979-95 panel, we used an iterative process to back out certain items needed for income averaging and AMT computations from the reported liabilities for those taxes.
} 
were calculated by incrementing each variable (either charitable contributions, unrealized capital gains on donations of appreciated asses, or long term capital gains) by ten cents, calculating the marginal increase in taxes owed, and dividing that by the ten cents.

To create the estimation sample, several cuts were made. All dependent filers and all taxpayers under the age of 25 were dropped from the sample, as were married taxpayers who filed separately and taxpayers with missing state data (in cases where we were not able to infer state from nearby years of data). To avoid endogenous sample selection, we then cut the data to include only those who would have itemized deductions even without any charitable contributions. To remove returns with internally inconsistent data, we dropped any returns where the federal income tax liability reported on the return was not sufficiently close to federal income tax liability figured by the tax calculator. ${ }^{25}$ Finally, we include only those taxpayers who are present in the sample and have the same marital status for at least six consecutive years. ${ }^{26}$ The resulting sample consists of 552,469 returns: 87,312 from the 1979-95 panel, 330,574 from the 1987-96 sample, and 134,583 from the 1999-2005 panel. 59,628 unique taxpaying units are represented. When we estimate our full econometric specification, the first two years and last two years of data for each taxpaying unit are omitted from the estimation sample, because we include two lagged changes and one- or two-year lead changes in price and income, and because as explained below, two years of future data are needed to compute our charitable donations variable. This reduces the number of observations to 294,513 .

\footnotetext{
${ }^{25}$ Specifically, we cut observations if the federal tax liability before credits and minimum taxes computed by the tax calculator differs from the amount reported in the dataset by more than $\$ 10,000$. Also note that before doing this, we made extensive efforts to resolve internal inconsistencies in the data by inferring values of problematic variables from information available elsewhere on the return.

${ }^{26}$ If a primary taxpayer is in the sample unmarried for at least six consecutive years and also in the sample married for at least six consecutive years, then both spells will be included in the estimation sample, but the primary taxpayer will be treated as belonging to different taxpaying units in the two spells for purposes of fixed effects analysis.
} 
For our estimation sample, the computed tax liability before credits and minimum taxes came very close to the corresponding amounts in the dataset, with correlations that round to 1.000 for the 1979-95 panel, 0.993 for the 1987-96 panel, and 1.000 for the 1999-2005 panel. The correlation between final federal tax liability (after credits and minimum taxes) computed by the calculator and reported in the data is in excess of 0.999 for all three panels.

Information on charitable contributions comes from the amounts reported on Schedule A of the federal income tax return. For itemizers, the amount of charitable deduction can differ from the amount of charitable donation because the deductible amounts of charity are limited to various percentages of a taxpayer's adjusted gross income (AGI), depending on the type of giving, and the total deduction may not exceed 50 percent of AGI. The amount of giving deducted in a particular year will exclude any portion of giving that is above those limits, and may include amounts carried over from a previous years in which the taxpayer gave in excess of a limit. Previous analyses of tax return data have used the current charitable deduction as the dependent variable, but we instead construct a variable that more closely approximates donations made in the current year. Tax return data reports the amount of the charitable deduction and the amount of carried-over prior year donations that are claimed and deducted in each year, but not the year from which these carried-over amounts originated. Our measure of charitable donation starts with the deductible amount in year $t$, subtracts any prior year donations that are carried over and claimed in year $t$, and then identifies any carryovers claimed in the next two years that are likely to have been originally donated in year $t$ and adds them to the donation amount for year $t$. To identify the probable original source years of carried-over contributions, we use information on whether the total charitable deduction, non-cash donations, or cash donations are at or above any of the relevant percentage of AGI limits in that year, and whether any carryovers are deducted in that year. ${ }^{27}$

\footnotetext{
${ }^{27}$ Full details on the algorithm used to re-allocate carried-over amounts across years are available in an appendix. Using the two-year carryover window algorithm, we are able to identify at least
} 
Charity in excess of the limits can be carried over for up to five years, but carryovers beyond two years are rare, and constructing the charitable donation variable in this manner requires dropping all observations that are not present in all of the future years used to find carryovers. So using a five-year window would dramatically shrink our sample. We report estimates from a sensitivity analysis that suggest that using a two-year window instead of a five year window to reallocate carryovers does not appreciably affect the estimates. ${ }^{28}$

Table 1 presents a description of the variables used in this study along with some descriptive statistics from the unweighted sample. In this sample, the mean amount of charitable giving is almost $\$ 140,000$ (in 2007 dollars). This large amount of giving is not surprising given the large number of very high-income taxpayers in this sample. The mean after-tax income in the sample is well in excess of $\$ 1$ million. Almost $85 \%$ of the sample consists of married taxpayers, and the average age of the primary taxpayer is 52 .

To better illustrate where identification of the coefficients of interest comes from in our sample, Figures 1 through 3 present time paths of the price and charitable giving variables used in the study, broken out by various groupings.

Figure 1 presents the average price of charitable giving by income class, where returns are classified according to the current year's income. Most of the variation in this graph comes from federal tax reforms. The effect of ERTA81 and TRA86 are striking, particularly for the top three income groups. For example, for the $\$ 1$ million and above group, the price of giving $\$ 1$ to a charity rose from $\$ 0.37$ in 1979 to $\$ 0.67$ by 1988, after the phase-in of TRA86 was complete. Also noticeable in this graph are the

one probable source year for 7,957 of the 12,245 carryovers reported in our estimation sample. The remaining 4,288 observations with carryovers that we could not allocate to one of the two previous years represent less than one percent of all observations in our final estimation sample.

${ }^{28}$ Another complication is that if deductible charity in the current year reaches $50 \%$ of AGI, then no further current-year donations of any kind may be deducted this year; rather they must be carried forward to a future year. At that point, the relevant marginal tax rate is from some future year. In these cases, when constructing the current "actual" price variable, we replace this year's marginal tax rate with an expectation of next year's marginal tax rate. This does not affect our instruments for price, since they are computed setting charitable donations to zero. 
effects of OBRA93, which particularly reduced the average price of giving for the highest three income groups, and EGTRRA2001 and JGTRRA2003, for which increases in the price of giving for the highest two income groups are apparent. For the two lowest income classes, the effects of the major federal tax reforms (with the exception OBRA93) are present, though much less noticeable. When we control for fixed effects and year dummies and limit the sample to upper-income people, the differing time paths of price among people in the high-income group shown in the bottom three lines in Figure 1 will be an important source of identification. Usefully, even among those with incomes of $\$ 200,000$ and above, prices did not move in lock-step, but the differences in time paths are subtle.

State tax variation is also quite important for identifying our price coefficients, so in Figure 2 we illustrate the effect that state income taxes have on the price of charitable giving for high-income people three selected large states: California, New York, and Ohio. Each of these states operated a large and progressive income tax throughout the sample period. California and New York allowed deductions for charitable contributions, and Ohio did not. The graph depicts, for people in each of these states with incomes above $\$ 200,000$ (in constant year 2007 dollars), an estimate of the difference between the average combined federal-state tax price of charitable giving, and what that price would be for similar individuals in a state without an income tax (such as Texas, Florida, or Washington). ${ }^{29}$ Figure 3 demonstrates that high-income people living in states with large income taxes had substantially different time-paths for the price of charity over the sample period, compared people in states with no income taxes. For instance, by the mid-1990s the California income tax reduced the price of giving $\$ 1$ to charity by about $\$ 0.14$, compared to just $\$ 0.03$ in 1981 . The New York income tax

${ }^{29}$ To prevent differences in income distributions across states and years from confounding the effects arising purely from variations in tax law, these average prices were calculated by drawing a random 10 percent sample of returns with incomes above $\$ 200,000$ (in 2007 dollars) from the 1985 SOI public-use cross section, and then using this same set of taxpayers to calculate the marginal impact of a charitable donation on combined federal-state tax liability, with and without state income taxes. We then compute weighted averages of the effect of the state income tax on price for each state-year cell, where the weights are designed to match the income distribution in our full estimation sample. 
reduced the price of giving $\$ 1$ to charity by about $\$ 0.12$ in the mid-1990s compared to a $\$ 0.03$ reduction in 1981. The Ohio state income tax slightly increased the price of giving $\$ 1$ to charity in the early 1980s, but reduced it by about $\$ 0.06$ by the mid-1990s. These patterns produce a quasi-experimental source of variation in price, where high-income people in states with large income taxes are like a treatment group and high-income people in states without income taxes are like a control group.

How a state income tax affects the price of charitable giving depends both on the design of the state's income tax and complicated interactions with the federal income tax. There were many changes in price caused by state tax reforms during the period, although the magnitudes of the changes were usually modest. ${ }^{30}$ A particularly large source of variation arises because of an interaction between state income taxes and a federal limitation on itemized deductions that began to apply in 1991 (and that persisted through the rest of the sample period). This accounts for the large drop in relative price evident in Figure 2 starting in 1991. Among people for whom itemized deductions were large as a share of income, this limitation was essentially a tax on AGI at the margin and had little or no impact on the price of charity. But if itemized deductions were small enough as a share of income, the effect of the limitation changed so that only $20 \%$ of charitable donations were deductible from the federal tax at the margin, dramatically increasing their price. In states with income taxes, those taxes essentially always made itemized deductions large enough to put people in the first category. But in states without income taxes, a substantial minority of high-income people had itemized deductions small enough to put them in the second category. ${ }^{31}$ Thus, starting in 1991,

\footnotetext{
${ }^{30}$ Some notable exceptions occurred in West Virginia and Louisiana, which eliminated itemized deductions during the sample period.

${ }^{31}$ For example, in our sample we estimate that from 1991 through 2005, the proportion of Texans with incomes above $\$ 200,000$ who had their price of giving increased by the itemized deduction limitation ranged from 6 percent to 28 percent depending on the year, with the differences largely driven by differences in sample composition (i.e., how heavily the sample was weighted towards very high-income people in that year). Although those are relatively small proportions, the impact on the price for those it affects is large enough that it shows up strikingly even in the averages.
} 
high-income people in states that operated income taxes avoided a large increase in the price of charitable giving that ended up applying to a non-trivial number of high-income people in states without income taxes.

Other federal-state interactions also loom large in Figure 2. Most importantly, because of the deductibility of state taxes from the federal income tax, a state deduction for charity causes a much larger reduction in the combined federal-state price of giving when federal marginal tax rates are low than when they are high. As federal marginal tax rates changed over time, this substantially changed the incremental effect of state income taxes on the overall price of giving; but no similar changes happened in states without income taxes or that did not allow deductions for charity. Interactions with the federal AMT are also important. For instance, people in high-tax states are far more likely to have to pay the AMT, which has a different pattern of marginal tax rates than the ordinary federal tax, and the AMT eliminates the deductibility of state taxes for those who are on it, which increases the incremental impact of state taxes on the price of giving. The federal AMT changed dramatically over time, and began to affect a large share of high-income returns after EGTRRA in 2001 and JGTRRA in 2003. ${ }^{32}$

To examine time patterns in the dependent variable during the sample period, Figure 3 presents charitable donations as a fraction of income, by income class. ${ }^{33}$ For the highest income groups, the time series pattern does seem broadly consistent with a responsiveness of charitable giving to persistent price variation -- charitable giving was typically a larger share of income early in the period when marginal tax rates were much higher. In addition, the time series evidence in Figure 3 displays elements that are consistent with people re-timing giving in response to anticipated future changes in price, although those effects appear to be confined largely to the very highest-income 32 See, for example, Burman, Gale, and Rohaly 2003. Useful state-level variation arises for other reasons as well -- for example, West Virginia and Louisiana both eliminated itemized deductions during the sample period.

${ }^{33}$ In Figure 3, a three year moving average of income was used, with capital gains realizations replaced by $6 \%$ of capitalized dividends, to smooth out the confounding effects of transitory fluctuations in income across years. 
groups. For those with income between $\$ 500,000$ and $\$ 1$ million and those with income in excess of $\$ 1$ million, there is a dramatic spike in giving in 1986, which makes sense given that in 1986 it was announced that the top federal marginal tax rate would drop from $50 \%$ to $28 \%$ by $1988 .{ }^{34}$ For millionaires, a smaller spike in giving in 1993 and 1994 is also consistent with timing behavior. Bill Clinton won the Presidential election in 1992 and had promised to raise marginal tax rates on the rich, which he did; early in 1993 a law was enacted that increased the top marginal rate from 31\% to 39.6\% starting in 1993 . A rich taxpayer anticipating this in 1992 could save taxes by delaying gifts that otherwise would have happened in 1992 until 1993 or 1994. Meanwhile, people with incomes between $\$ 200,000$ and $\$ 500,000$ had only slightly smaller incentives to re-time giving around the 1986 and 1993 tax changes (as illustrated in Figure 1), yet the time series patterns in Figure 3 reveal little or no re-timing of giving in response to these incentives. This corroborates our suspicion that heterogeneity of responsiveness across income classes may be important.

\section{Estimates, primary specification}

Table 2 presents estimates of equation (1) using the full sample, along with some sensitivity analyses to demonstrate how certain aspects of the specification affect the estimates. Here we pool people of all income levels together, and control for fixed effects and year dummies. The time dummies remove time series variation in the average of tax rates across the whole sample from the identifying variation, and the fixed effects remove from the identifying variation differences in tax rates across people that are constant across time (due, for example, to persistent cross-sectional differences in income). The remaining identifying variation includes the fact that federal tax reforms changed marginal tax rates in different ways over time for people at different income levels, so for example moderate income people who had little change in

${ }^{34}$ The spike in giving among high-income people in 1986 has been noted before, for example in Auten, Cilke, and Randolph (1992). 
marginal tax rates over the period serve as a control group for high income people who had large changes in marginal tax rates over the period. In addition, identifying variation for price comes from different time paths of tax rates across states, arising from changes in state tax laws and interactions between state tax law and changes in federal law. Finally, identification for price effects also comes from idiosyncratic shocks to income (that cannot otherwise be explained by the covariates in the model) to the extent that the resulting changes in price are non-linear functions of those shocks. Income effects are identified by changes in federal and state tax liabilities of a nature similar to those identifying marginal tax rate changes (e.g., they changed in different ways over time for different income classes), and also by idiosyncratic shocks to income that cannot be explained by the other covariates (e.g., they differ from the average shocks for the sample as a whole, which are controlled for by the year dummies, and they differ from the average life-cycle effects for the sample as a whole).

As a check on the strength of the identification provided by our instruments, we perform the Anderson canonical correlation test and the Cragg-Donald weak identification test for all equations. These tests reject the null hypothesis of weak identification for every regression reported in our paper, with a p-value that rounds to 0.0000. This suggests that small-sample bias arising from weak instruments is unlikely to be a problem. ${ }^{35}$

In column (1) of Table 2, we report estimates from our preferred specification, which uses the changes in price and income between year $t$ and year $t+2$ as our measures of future price and income changes, and which instruments for these future changes using the "predictable tax change" strategy described above. The elasticity of charitable giving with respect to a persistent increase in price is estimated to be -0.707 , and is highly statistically significant with a standard error of 0.254 . The elasticity of current giving with respect to a future price increase is estimated to be just -0.083 with a standard error of 0.266 . If timing behavior were important for the sample as a whole, we

35 The first stage regressions for the 2SLS regression presented in Table 3, column (1), as well as the regressions used to predict income changes that we use to help us construct the predictable tax change instruments, are available in an appendix. 
would expect a positive coefficient on the future price increase (as people would respond to an anticipated future increase in price by giving more today). The confidence interval does not enable us to rule out a moderate positive coefficient on the future price change, but there is certainly no conclusive evidence of timing here.

A positive coefficient on the lagged change in price suggests that people only gradually change their giving in response to a change in price. We consistently find positive coefficients on lagged price changes in specifications reported throughout the paper. In column (1) of Table 2 , the 0.155 estimate on the one-year lagged change in log price implies that if price goes up by one percent this year, there is a $-0.707+0.155=-$ 0.552 percent change in charitable giving, whereas if the price went up by one percent last year and stayed at that level this year (so that $\Delta \ln P_{t}$ was zero), then other things equal there would be a -0.707 percent change in charity relative to its level two years ago. Thus, the impact of the price change is estimated to be larger in the second year it is in effect than in the first year, which would be consistent with gradual adjustment, perhaps because it takes time learn about the law or to change habits and commitments. The positive coefficient on lagged price changes is the opposite of what one would expect if people were re-timing giving across years in response to one-year blips in price that were known to be transitory. In that case, there should be a negative coefficient on the lagged change in price. If the price is higher this year than it was last year and timing behavior were important, then other things equal we would expect less charitable giving this year, as people would have moved giving from the current year into the prior year in anticipation of the price increase that would take effect this year. However, it is possible that, because of the way tax reforms are phased-in over time, changes in price are positive serially correlated over time conditional on the other covariates -- i.e., if price is higher this year than it was last year, you expect it to be higher still next year. In that case, the positive coefficient on lagged price change could be consistent with timing behavior, as an increase in price this period makes one want to give more to charity now before price increases again next year. 
At the bottom of the table, we report a "transitory price elasticity," which in this study represents the effect on current charity of an increase in this period's price relative to last year that is expected to go away in the future. As noted above, this is derived from the sum of the coefficients on $\Delta \ln P_{t}$ and $\ln P_{t}$, minus the coefficient on $\Delta \ln P_{\text {future. }}$. We estimate the transitory price elasticity to be -0.469 with a standard error of 0.043 . That this estimate is smaller than the persistent price elasticity of -0.707 is also inconsistent with timing behavior -- it suggests, counter-intuitively, that charitable giving is less responsive to a "one time sale" than it is to a more persistent reduction in price of the same magnitude. The fact that timing behavior does not show up strongly in estimates using the entire sample should perhaps not be surprising when we consider the time series patterns of giving for different income classes depicted in Figure 3. Evidence of timing behavior there was largely confined to those with incomes above $\$ 500,000$, with little sign of timing in any income groups below that despite some reasonably strong incentives to re-time for some of these groups. This finding is also consistent with the study of Auten, Sieg, and Clotfelter, which finds the transitory price elasticity to be smaller than the persistent price elasticity in most specifications.

The estimates of income elasticities in column (1) of Table 2 are highly consistent with the permanent income hypothesis. We find the elasticity of charity with respect to a persistent income change to be 0.906 with a standard error of 0.164 . In contrast to the lack of evidence of responsiveness to future price changes, we estimate that current charitable giving increases by 0.527 percent in response to an anticipated one percent increase in future after-tax income, with a standard error of 0.179 . This finding suggests that if a tax reform enacted today but does not reduce tax liability until one or two years in the future, people will nonetheless respond by immediately increasing their expenditures on charity. The response is smaller than it is to a persistent change in income that has already taken effect, though, suggesting that there is far from perfect consumption smoothing over time.

The negative coefficients on lagged income changes are also consistent with the permanent income hypothesis if there is a mean-reverting income process. Ceteris 
paribus, if income today is higher than it was last year or two years ago, then part of that increase probably reflects a transitory upward blip in income that is expected to go away in the future. Thus, when the lagged changes in income are positive, less is given to charity today than would be if the lagged changes were zero, because in the former situation high current income reflects transitory income, whereas in the latter situation a high current income reflects more persistent variation in income. The coefficient on $\Delta \ln Y_{t}$ of -0.128 with a standard error of just 0.006 , for example, is highly consistent with this story, as is the positive and significant but smaller coefficient on $\Delta \ln Y_{t-1 .}$. The elasticity of charity with respect to a transitory income change, which combines information from the coefficients on $\Delta \ln Y_{t}, \ln Y_{t}$, and $\Delta \ln Y_{\text {future }}$ in a manner analogous to the transitory price elasticity, is estimated to be 0.251 , which is much smaller than response to a persistent income change, although this effect is highly statistically significant with a standard error of 0.017 .

In column (2) of Table 2, we present estimates from a specification similar to that shown in column (1), except that we now assume perfect foresight about future price and income changes. These estimates demonstrate that, relative to the perfect foresight assumption that is frequently used in the empirical tax literature, our "predictable tax changes" instrument strategy makes a big difference to the estimated income elasticities, making them more consistent with the permanent income hypothesis, but has a smaller impact on the price elasticities. Assuming perfect foresight reduces the estimated persistent income elasticity from 0.906 to just 0.487 , although it remains highly statistically significant, with a standard error of 0.017 . The elasticity of current giving with respect to a future income drops from 0.527 to just 0.049 . This too remains highly statistically significant, though, with a standard error of 0.007 . This is exactly what we would expect if our "predictable tax change" instrumental variables strategy were correcting the errors-in-variables bias inherent in the perfect foresight approach. In the perfect foresight equations, classical measurement error would be expected to bias the estimated effects of persistent income variation and expected future income increases towards zero. If our "predictable tax change" instruments are valid (e.g., they are 
strongly correlated with the expectation of the future change in income, and are uncorrelated with the forecast error), then we would expect them to correct the bias and lead to larger estimated elasticities, which they do.

Interestingly, switching to the perfect foresight approach from the predictable tax instrument approach has much smaller effects on the estimated price elasticities. The persistent price elasticity in the perfect foresight approach in column (2) is reduced slightly to -0.615 , and it remains statistically significant with an 0.074 standard error. The elasticity of giving today to an expected future price increase is now of the right sign and statistically significant, but the magnitude is small at 0.143 (with a standard error of 0.038). The transitory price elasticity, estimated at -0.52 , remains a bit smaller than the persistent price elasticity. Overall, this suggests that the perfect foresight assumption may bias the persistent price elasticity towards zero, but just by a bit. The perfect foresight estimates do suggest some moderate timing behavior, at least in response to anticipated future price changes. The perfect foresight specification does have one notable advantage -- the standard errors on the responses to future price changes and future income changes in particular are much smaller than in the "predictable tax change" instrument specification. Predictable future changes in log price and log income arising from tax reforms are sometimes only subtly different from each other and thus fairly collinear. For instance, when a reform is enacted that cuts future marginal tax rates, it usually also cuts future tax liabilities, and since both should increase current charitable giving, it can be hard to distinguish which is most responsible for a current change in giving. The perfect foresight approach adds actual future changes in pre-tax income to the identifying variation, which provides more information with which to distinguish future income changes from future price changes. The greater precision in the perfect foresight regressions is of limited help, though, if the coefficients are biased because the instruments are contaminated by forecast error.

In columns (3) and (4), we report estimates from regressions that are similar to those reported in columns (1) and (2), respectively, but that use the one-year-ahead changes in price and income instead of the changes over the next two years. The 
estimates are largely similar to those using the two-year future changes. The most notable difference is that the elasticities of giving with respect to persistent income changes and anticipated future income changes are somewhat smaller than when we use the two-year future changes in price and income. For example, in the predictable tax change instrument approach, using the one-year future changes instead of the two-year future changes reduces the persistent income elasticity from 0.906 to 0.8 , and reduces the elasticity with respect to future income change slightly from 0.527 to 0.482 . Both remain highly statistically significant. In sensitivity analyses presented below in Tables 4 through 7, we will focus on specifications using changes in price and income over the next two years, because of the ubiquity of federal tax reforms that are phased in over at least two years after enactment, and because this seems to work slightly better than the $\mathrm{t}+1$ approach for separating persistent from transitory variation in income.

In column (5) of Table 2, we show estimates from a model that includes lagged changes in price and income, but omits future changes in price and income, to show the consequences of ignoring forward-looking behavior. The coefficients on $\ln P_{t}$ and $\ln Y_{t}$ still represent elasticities of giving with respect to persistent price and income changes in the sense that they estimate the change in giving in response to a change in price or income that has persisted for three years, but they do not take into account any anticipated changes in future prices or incomes. In this specification, the persistent price elasticity remains similar at -0.743 , but the persistent income elasticity is quite low at just 0.448. Finally, in column (6) of Table 2, we remove the lagged changes in prices and income as well. Here, the price elasticity is estimated at -0.671 , but the income elasticity drops to just 0.328 . The low income elasticity is what we would expect if people respond more to persistent variation in income than to transitory fluctuations in income, as the income elasticity in this specification is measuring responses to a mix of transitory and persistent changes in income.

Table 2 also reports the estimated effects of the various control variables. Briefly, number of children and number of other dependents are both estimated to have positive and significant effects on giving, and age squared has significant negative effects in the 
specifications assuming perfect foresight or omitting lead changes in price and income. Estimates for state-year-specific variables generally have confidence intervals too wide to say anything conclusive. Because these variables are not our main concern in this paper, we will omit reporting their coefficients in the remaining fixed effects specifications, while still controlling for them. ${ }^{36}$

\section{Estimates allowing for parameter heterogeneity across income classes}

Our first approach to allowing for heterogeneity across income groups attempts to replicate the story that comes through from Figures 1 and 3. In this approach, we split the sample into different groups selected by average income levels, but we do not control for year dummies in each sample, as this would absorb the aggregate time series variation in federal tax rates that produces the strongest signal to people to re-time their giving. In each income sample, we use the same approach and same set of covariates as we did in column (6) of Table 2, including fixed effects, except that we omit year dummies and replace them with an income class-specific quadratic time trend and an income-class specific effect of the log real S\&P500. In this approach, identification for price variation comes from the fact that federal tax rates changed over time within an income class in ways that did not conform to a smooth quadratic time trend. Thus, for example, most of the identification arising from the relatively sharp discrete changes in federal tax rates arising from TRA86 and OBRA93 is preserved in this specification. As in all of our other specifications, identification is added by different time paths of price caused by state tax variation, and variation in price caused by idiosycratic shocks to income where price changes are nonlinear functions of those shocks.

Table 3 depicts the results of this exercise, and it does indeed match Figure 3 fairly well. Most notably, a strong timing response to anticipated future change in price is found for the two highest income groups. For taxpayers with average incomes of $\$ 1$

\footnotetext{
${ }^{36}$ We also tried omitting the state variables from selected fixed effects equations, and found that this had essentially no effect on the estimates.
} 
million or above (column 4), a one percent increase in future price, holding current price constant, is estimated to increase current giving by 0.757 percent with a standard error of 0.296 . The persistent price elasticity is a modest -0.493 with a standard error of 0.276 , while the transitory price elasticity is now large at -0.916 . For all taxpayers with average incomes of $\$ 500,000$ or above (column 3), the basic story is similar, although the estimated timing effects are a bit less pronounced, and the -0.483 persistent price elasticity is now significant at the $5 \%$ level. Thus, when we allow for heterogeneous response across income classes and preserve most of the identification arising from discontinuous time series variation in federal tax rates, timing phenomena like the spike in 1986 giving do seem to show up in our estimates. In both the $\$ 500,000$ and above and $\$ 1$ million and above samples, the persistent income elasticity is around 0.6, with no significant response to anticipated future income changes.

When the sample is expanded to include everyone with incomes above $\$ 200,000$, the evidence of timing effects largely disappears, and the estimates are largely similar to those we saw back in column 1 of Table 2 . The persistent price elasticity is estimated to be -0.654 with a 0.195 standard error, the persistent income elasticity is 0.783 with a 0.115 standard error, and there is once again a significant response to anticipated future income changes. Finally when this particular specification is estimated on the sample of taxpayers with incomes below $\$ 200,000$, it appears to be weakly identified, with large standard errors and very small persistent price and income effects.

The drawback of the specification in Table 3 is that it does not control for unobservable time varying influences on charitable giving in a very flexible fashion, so that we might worry that, for example, our estimates of the effects of persistent price and income changes could be confounded with the effects of other factors that were changing over time in a fairly non-linear way. At the same time, because we are not controlling for time effects in a completely flexible way, this identification strategy does a good job of pinpointing the times when there was a really large incentive to re-time giving. The estimate of a large response among very high income people to obvious 
timing incentives around TRA86 and OBRA93 seems reasonable -- for instance, there is no other apparent reason for there to be a spike in charitable giving in 1986.

In Table 4, we try an alternative method of allowing for heterogeneity across income classes and controlling for time-varying unobservable influences on charity. In this specification, the quadratic time trend and S\&P500 variable are replaced with year dummies (time effects), and the time effects are assumed to be common across all income classes. We implement this by first running regressions of the dependent variable, explanatory variables, and instruments on year dummies using the full sample, and then using the residuals in the regressions estimated on samples limited to particular income classes. The purpose of this is to allow different time paths of federal tax rates across different income classes to contribute to the identification of our model. In this approach, we are effectively controlling for any influences on charitable giving that are changing in the same way for everyone in the nation over time, but we must assume that there are no omitted influences on charitable giving that change in different ways over time across income classes in a way that is correlated with tax changes. Here, an individual's federal tax changes identify our model to the extent that they differ from the average change in federal tax rates for the sample as a whole. So, for example, we are taking out the changes in price in Figure 1 that apply to everyone (such as the gradual upward drift in prices for the sample as a whole). And as before, different time paths of price arising from state tax variation, as well as changes in price coming from idiosyncratic shocks in income fed through the tax function, both contribute to price effect identification. Compared to the specification in Table 3, this approach allows for a more flexible time path of unobservable influences, but allows less scope for variation across income classes in the time paths of those unobservables.

The basic story arising from Table 4 is that when we control for common time effects and allow for heterogeneous parameters across income classes, the evidence of timing effects disappears, and estimated persistent price elasticities are larger and strongly statistically significant, with evidence of larger elasticities for the highestincome classes. The persistent price elasticity rises from -0.699 for returns with incomes 
below $\$ 200,000$ to -0.772 for all returns with incomes of $\$ 200,000$ or above, -0.832 for returns with incomes of $\$ 500,000$ and above, and -1.079 for returns with incomes of $\$ 1$ million and above. All are strongly statistically significant. The estimated effects of future price changes are near zero for all income classes, but with wide confidence intervals. One reasonable interpretation may be that controlling for even common time effects removes much of the identification arising from pre-announced sharp discontinuous changes in federal tax rates that applied with only moderate degrees of variation to large numbers of people in the sample, such as that caused by TRA86. This sort of variation may be particularly easy for taxpayers to identify and thus is more salient; the remaining variation in tax law used to identify predictable future changes in price were usually more subtle in nature -- in this specification anticipated future changes in federal tax rates only identify the model to the extent that those changes differ across income levels. Chetty, Looney, and Kroft (2007) among others have empirically demonstrated that the magnitude of the behavioral response to a tax can depend on its salience. At the same time, interestingly, Table 4 again finds relatively strong evidence of people responding to anticipated future changes in income, except when the sample is restricted to the very highest income slices. The elasticity of charitable giving with respect to a future increase in income is estimated at 0.56 for returns with incomes below $\$ 200,000$ and 0.398 for returns with incomes of $\$ 200,000$ or above. Estimated persistent income elasticities are also consistently larger in Table 4 than in Table 3, for instance 0.846 below $\$ 200,000$ and 0.806 for those with incomes $\$ 200,000$ or above. Transitory income elasticities are estimated to be considerably smaller than persistent income elasticities, again consistent with the permanent income hypothesis.

Table 5 displays estimates from estimates using our least restrictive identification strategy. In this table, the sample is split into different income classes, and each income class has its own year dummies. These specifications are the same as that in Table 2, column (1), except that the sample is limited to people with average incomes above some threshold. The income-class specific year dummies effectively control for any 
unobservable influences on charity that are changing in the same way over time for everyone in the income class, but which may be changing in different ways over time for different income classes. This approach subsumes factors such as the income-class specific quadratic time trends and stock price effects that we controlled for in Table 3, in addition to any other arbitrary time path of unobservable influences that is common for people in the same income class. $\mathrm{n}$ this specification, all of the identification for price variation must come from differences between the time path of federal and state tax rates for the individual, and the average time path for people in the same income class. For the highest two income slices (\$500,000 and above and $\$ 1$ million and above), this removes almost all identification from federal tax variation, because these taxpayers were essentially always in the top tax bracket and thus had similar changes over time to others in the same income class. Identification from different time paths of price across states remains, as does identification arising from idiosyncratic shocks to income fed through the non-linear tax function. For the group with incomes of $\$ 200,000$ or above, identification is a bit stronger -- when the group is expanded in that way there are now somewhat different time paths of federal taxes across different income levels, and also more identification provided by the AMT. When the sample is limited to returns with income below $\$ 200,000$ and heterogeneous time effects by income class are allowed, we found that identification was extremely weak and standard errors blew up, so we do not report these results. There was not much variation across individuals in time paths of federal or state tax rates when the sample is restricted to those with incomes below $\$ 200,000$.

Although the estimates are imprecise for the two highest income slices, the estimates in Table 5 basically corroborate the findings in Table 4. For taxpayers with incomes above $\$ 200,000$ as a whole, we find a large and statistically significant persistent price elasticity of -1.157 with a standard error of 0.433 . For the $\$ 500,000$ and above and $\$ 1$ million and above categories, the point estimates for the persistent price elasticity are similarly large or larger, although the standard errors are also fairly large. Nonetheless, the general similarity of the point estimates here to those in Table 4 provide no reason to 
believe that omitted influences on charity that changed in different ways over time in different income classes are driving the persistent price elasticity estimates that we found in Table 4. As in Table 4, Table 5 reveals little evidence of timing behavior, although this too may arise because we have removed the most salient signals of timing incentives from the identifying variation. Persistent income elasticities are moderately large and statistically significant in Table 5. For the $\$ 200,000$ and above group, the persistent income elasticity is estimated to be 0.777 , and we again find evidence that people increase giving now in response to an expected future income increase, with the elasticity estimated at 0.373 . The transitory income elasticity for the $\$ 200,000$ and above group is again considerably smaller than the persistent income elasticity, at 0.271.

\section{Estimates using alternative measures of charity}

In Table 6, we investigate the effects of using alternative measures of charitable giving as the dependent variable. In all of our specifications thus far, our dependent variable has been defined as the current charitable deduction in year $t$, less carryovers from prior years, plus any carryovers claimed in the next two future years that various indicators suggest probably came from year $t$. To facilitate comparisons, column (1) of Table 6 repeats the estimates from our preferred specification estimated on the full sample (previously shown Table 2, column (1)). In column (2), we show estimates of the same specification estimated on the same sample, except now the dependent variable is the current charitable deduction (excluding current donations over the limits and including carryovers from prior years). The persistent price elasticity is quite similar at about -0.7 under either specification. The most significant difference is that when the current deduction is used as the dependent variable instead of our measure of current donation, the transitory price elasticity is considerably larger (-0.730 vs. -0.469$)$. Because current deduction includes carryovers in the years when they are deducted, whereas current contribution reallocates most carryovers to the year they are donated, this might suggest that people are particularly willing to change when they choose to deduct 
carryovers in response to timing incentives. The other notable difference is that when current deduction is used as the dependent variable, the estimated income elasticity is slightly higher, 1.033 versus 0.906 . The direction of the effect is consistent with the bias we would expect from the mechanical relationship where people with higher incomes have larger charitable deductions because more of their charity fits under the percentage of AGI limitations. Overall, however, Table 6 suggests that using current charitable donation instead of current charitable deduction does not make a huge difference.

In columns (3) and (4) of Table 6, we investigate the effect of limiting our search for carryovers that may have been donated in year $t$ to a two year window of future years instead of a five year window. The drawback to using a longer window is that we must remove from the estimation sample observations from all of those future years. The five year window leaves a much smaller sample and forces us to omit many whole years of data spanning tax reforms that provide some of the best sources of identification. As such, we found that our preferred specification was weakly identified when we used the five year carryover window and the predictable tax change instruments, so we instead report results of a sensitivity analysis assuming perfect foresight. In both columns (3) and (4), we limit the sample to those observations that have data for all five lead year and estimate the perfect foresight model with 2-year lead changes in price and income. Column (3) uses donations computed with a two year carryover window, and column (4) uses donations computed with a five year carryover window. As is evident from Table 6, the estimates using either measure of charity are extremely similar. ${ }^{37}$

\section{Pooled cross-section estimates}

In Table 7 we report estimates from specifications that omit both fixed effects and lag and lead changes in price and income, in order to verify that our data yield estimates

\footnotetext{
${ }^{37}$ When we used the predictable tax change instrument approach, we also found that parameter estimates were similar whether we used the two-year window donations or the five-year window donations. The problem was just that the standard errors were very large.
} 
roughly similar to the old cross-sectional literature when we use similar sources of identification. Column (1) estimates such a model that also omits the state-level control variables, while column (2) adds back the state characteristics. In both of these specifications, the price of giving is instrumented using the first dollar price. Columns (3) and (4) present results from this specification where the sample is broken out by income group.

In the most basic specification, the price elasticity of charitable giving is estimated to be -0.816 with a standard error of 0.129 , and the income elasticity is estimated to be 0.827 , with a standard error of 0.018 . This price elasticity is somewhat below the standard estimate of from single year cross-sectional studies around -1.2 noted in Clotfelter (1985) for estimates of this type, and the income elasticity is only slightly higher than the standard estimate of around 0.7. One possible explanation for the modest differences in estimates compared to traditional single-year cross section studies is that we are here using a pooled set of cross sections from a large number of years that span widely varying federal and state tax laws, which provides greater independent identification for price and income variation and should reduce any biases arising from misspecification of functional form and difficulty disentangling price effects from income effects. Controlling for state level characteristics has no appreciable effect on these estimates. ${ }^{38}$

When the sample is divided into those with income less than $\$ 200,000$ and those with income in excess of $\$ 200,000$, the estimated price elasticity for the low income group is -0.477 , while the price elasticity for the high income group is -1.287 ; both are

\footnotetext{
38 We also tried a version of equation (2) in Table 7 that approximately replicated the approach used in Feenberg (1987), where an estimate of the average state-year specific price (calculated using a sample of taxpayers that is constant across state and time) was used as an instrument for price, so that all the identification for price variation came from differences in state tax law and its interaction with federal law, and none of the identification for price came from variation in income. In these specifications, estimated price elasticities were again in the vicinity of -0.7. However, we found that clustering the standard errors by state (the importance of which was not yet recognized 1987) increased the standard errors dramatically so that we were unable to say anything conclusive based on these regressions.
} 
highly statistically significant. This provides corroborating evidence of parameter heterogeneity across income groups using a different source of identification.

Table 7 also depicts estimates of the effects of the various control variables. In the cross section, many of these factors have statistically significant and sensible effects. Age, marriage, children, and dependents are each estimated to have a positive partial association with charitable giving. Church attendance in one's state is estimated to have a particularly large positive impact on giving, although the effect becomes smaller and very imprecisely estimated when the sample is limited to those with incomes above $\$ 200,000$. Higher state government spending has a positive partial association with charitable donations, which is the opposite of "crowd out," although the estimates are imprecise. Estimates for other variables vary depending on the sample. For instance, higher house prices are estimated to increase charity among people with incomes below $\$ 200,000$ but reduce charity for those with incomes above $\$ 200,000$.

\section{Conclusions}

In this study, we have estimated a fairly flexible model of the effects of price and income on charitable giving, allowing for two lags and two period leads of changes in price and income to affect current giving, controlling for fixed effects, allowing for different responsiveness to incentives by people at different income levels, and in some cases controlling for different time paths of unobservable influences on charity across income groups. The use of a federal-state tax calculator in conjunction with Treasury panel data spanning many federal and state tax reforms and containing a large selection of high income people enables us to follow such a flexible approach and to implement a more demanding identification strategy than has been previously used in the literature. We develop an instrumental variables strategy for estimating the effect of expected future changes in prices and incomes that relies on predictable changes in taxation for identification, and we show that this yields substantially larger responses to persistent income and anticipated future changes in income compared to a model that assumes 
perfect foresight. Together with the fact that transitory income elasticities are estimated to be considerably smaller than persistent income elasticities, the evidence is largely consistent with the permanent income hypothesis. For the sample as a whole, the estimated persistent price elasticity is about -0.7. Estimates of the persistent price elasticity tend to be larger when the sample is restricted to high-income people and we control for time-varying unobservable influences on charity in a flexible manner. We find strong evidence of timing behavior in response to predictable future changes in the price of giving only when the sample is limited to very-high income returns (with average incomes over time in excess of $\$ 500,000)$ and when identification for price effects includes particularly salient time-series variation in federal taxes. Otherwise, point estimates of timing responses tend to be small, and are imprecisely estimated in the predictable tax change instrument approach. The estimates in our present paper do suggest that, for high-income taxpayers at least, there is fairly robust evidence that charitable giving is fairly responsive to persistent changes in tax incentives. Other things equal, this generally strengthens the case for some form of subsidy to charitable giving. 
Table 1 -- Descriptive Statistics

\begin{tabular}{|c|c|c|c|}
\hline Variable & Description & Mean & Std. Dev. \\
\hline charity & Total charitable contributions & 139,729 & $5,397,826$ \\
\hline $\ln P$ & $\begin{array}{l}\text { Actual log price of giving (defined } \\
\text { in text) }\end{array}$ & -0.43 & 0.18 \\
\hline $\ln P_{0}$ & $\begin{array}{l}\text { First dollar log price of giving } \\
\text { (defined in text) }\end{array}$ & -0.43 & 0.17 \\
\hline$Y$ & $\begin{array}{l}\text { After-tax income, defined as pre- } \\
\text { tax income minus federal and state } \\
\text { income tax liabilities, minus tax } \\
\text { savings from charitable } \\
\text { contributions. }\end{array}$ & $1,424,906$ & $7,390,045$ \\
\hline married & $\begin{array}{l}\text { Dummy equal to } 1 \text { if taxpayer is } \\
\text { married filing jointly }\end{array}$ & 0.85 & 0.36 \\
\hline age & Age of primary taxpayer & 52.20 & 12.97 \\
\hline children & Number of children at home & 0.43 & 0.84 \\
\hline other dependents & Number of other dependents & 0.61 & 1.05 \\
\hline $\ln P_{\text {_salestax }}$ & $\begin{array}{l}\text { Effect of state retail sales tax on } \\
\text { relative price of charity }\end{array}$ & -0.05 & 0.01 \\
\hline In(state house price) & State log median real housing price & 11.97 & 0.37 \\
\hline state unemployment & State unemployment rate & 0.06 & 0.02 \\
\hline church & $\begin{array}{l}\text { Share of state attending church } \\
\text { weekly, } 2006\end{array}$ & 0.39 & 0.08 \\
\hline state gov't spending & $\begin{array}{l}\text { State and local government } \\
\text { spending as a share of state } \\
\text { personal income }\end{array}$ & 0.18 & 0.03 \\
\hline
\end{tabular}

Table depicts unweighted means. All dollar figures are in constant year 2007 dollars, adjusted for inflation using the CPI-U. 
Table 2 -- Explaining log charitable giving: all incomes, with fixed effects and year dummies

\begin{tabular}{|c|c|c|c|c|c|c|}
\hline & (1) & (2) & (3) & (4) & (5) & (6) \\
\hline & $\begin{array}{c}\mathrm{t}+2 \text { leads, } \\
\text { predictable } \\
\text { tax change } \\
\text { instruments }\end{array}$ & $\begin{array}{c}\mathrm{t}+2 \text { leads, } \\
\text { perfect } \\
\text { foresight }\end{array}$ & $\begin{array}{c}\mathrm{t}+1 \text { leads, } \\
\text { predictable } \\
\text { tax change } \\
\text { instruments }\end{array}$ & $\begin{array}{c}\mathrm{t}+1 \text { leads, } \\
\text { perfect } \\
\text { foresight }\end{array}$ & $\begin{array}{c}\text { Two lags, } \\
\text { no leads }\end{array}$ & $\begin{array}{c}\text { No lags or } \\
\text { leads }\end{array}$ \\
\hline$\Delta \ln P_{t-1}$ & $\begin{array}{l}-0.015 \\
(0.049)\end{array}$ & $\begin{array}{c}0.040 \\
(0.039)\end{array}$ & $\begin{array}{l}-0.001 \\
(0.049)\end{array}$ & $\begin{array}{c}0.043 \\
(0.039)\end{array}$ & $\begin{array}{c}0.047 \\
(0.038)\end{array}$ & \\
\hline$\Delta \ln P_{t}$ & $\begin{array}{c}0.155 \\
(0.058)^{* *}\end{array}$ & $\begin{array}{c}0.237 \\
(0.050)^{* *}\end{array}$ & $\begin{array}{c}0.190 \\
(0.057)^{* *}\end{array}$ & $\begin{array}{c}0.246 \\
(0.050)^{* *}\end{array}$ & $\begin{array}{c}0.240 \\
(0.049)^{* *}\end{array}$ & \\
\hline $\begin{array}{l}\ln P_{t} \text { [persistent } \\
\text { price elasticity] }\end{array}$ & $\begin{array}{c}-0.707 \\
(0.254)^{* *}\end{array}$ & $\begin{array}{c}-0.615 \\
(0.074)^{* *}\end{array}$ & $\begin{array}{c}-0.680 \\
(0.147)^{* *}\end{array}$ & $\begin{array}{c}-0.649 \\
(0.072)^{* *}\end{array}$ & $\begin{array}{c}-0.743 \\
(0.074)^{* *}\end{array}$ & $\begin{array}{c}-0.671 \\
(0.045)^{* *}\end{array}$ \\
\hline$\Delta \ln P_{\text {future }}$ & $\begin{array}{l}-0.083 \\
(0.266)\end{array}$ & $\begin{array}{c}0.143 \\
(0.038)^{* *}\end{array}$ & $\begin{array}{l}-0.017 \\
(0.157)\end{array}$ & $\begin{array}{c}0.136 \\
(0.039)^{* *}\end{array}$ & & \\
\hline$\Delta \ln Y_{t-1}$ & $\begin{array}{c}-0.059 \\
(0.007)^{* *}\end{array}$ & $\begin{array}{c}-0.059 \\
(0.007)^{* *}\end{array}$ & $\begin{array}{c}-0.055 \\
(0.006)^{* *}\end{array}$ & $\begin{array}{c}-0.059 \\
(0.007)^{* *}\end{array}$ & $\begin{array}{c}-0.060 \\
(0.007)^{* *}\end{array}$ & \\
\hline$\Delta \ln Y_{t}$ & $\begin{array}{c}-0.128 \\
(0.006)^{* *}\end{array}$ & $\begin{array}{c}-0.141 \\
(0.009)^{* *}\end{array}$ & $\begin{array}{c}-0.122 \\
(0.008)^{* *}\end{array}$ & $\begin{array}{c}-0.140 \\
(0.009)^{* *}\end{array}$ & $\begin{array}{c}-0.143 \\
(0.009)^{* *}\end{array}$ & \\
\hline $\begin{array}{l}\ln Y_{t} \text { [persistent } \\
\text { income elasticity] }\end{array}$ & $\begin{array}{c}0.906 \\
(0.164)^{* *}\end{array}$ & $\begin{array}{c}0.487 \\
(0.017)^{* *}\end{array}$ & $\begin{array}{c}0.800 \\
(0.129)^{* *}\end{array}$ & $\begin{array}{c}0.478 \\
(0.018)^{* *}\end{array}$ & $\begin{array}{c}0.448 \\
(0.015)^{* *}\end{array}$ & $\begin{array}{c}0.328 \\
(0.011)^{* *}\end{array}$ \\
\hline$\Delta \ln Y_{\text {future }}$ & $\begin{array}{c}0.527 \\
(0.179)^{* *}\end{array}$ & $\begin{array}{c}0.049 \\
(0.007)^{* *}\end{array}$ & $\begin{array}{c}0.482 \\
(0.168)^{* *}\end{array}$ & $\begin{array}{c}0.043 \\
(0.008)^{* *}\end{array}$ & & \\
\hline InP_salestax & $\begin{array}{l}-0.191 \\
(0.650)\end{array}$ & $\begin{array}{c}0.196 \\
(0.831)\end{array}$ & $\begin{array}{l}-0.252 \\
(0.638)\end{array}$ & $\begin{array}{c}0.186 \\
(0.818)\end{array}$ & $\begin{array}{c}0.212 \\
(0.826)\end{array}$ & $\begin{array}{c}0.642 \\
(0.856)\end{array}$ \\
\hline (age/100) squared & $\begin{array}{c}0.202 \\
(1.374)\end{array}$ & $\begin{array}{c}-2.790 \\
(0.492)^{* *}\end{array}$ & $\begin{array}{l}-0.298 \\
(1.149)\end{array}$ & $\begin{array}{c}-2.794 \\
(0.493)^{* *}\end{array}$ & $\begin{array}{c}-2.897 \\
(0.498)^{* *}\end{array}$ & $\begin{array}{c}-4.627 \\
(0.515)^{* *}\end{array}$ \\
\hline children & $\begin{array}{c}0.027 \\
(0.005)^{* *}\end{array}$ & $\begin{array}{c}0.029 \\
(0.006)^{* *}\end{array}$ & $\begin{array}{c}0.027 \\
(0.005)^{* *}\end{array}$ & $\begin{array}{c}0.029 \\
(0.006)^{* *}\end{array}$ & $\begin{array}{c}0.030 \\
(0.006)^{* *}\end{array}$ & $\begin{array}{c}0.040 \\
(0.005)^{* *}\end{array}$ \\
\hline other dependents & $\begin{array}{c}0.023 \\
(0.005)^{* *}\end{array}$ & $\begin{array}{c}0.028 \\
(0.006)^{* *}\end{array}$ & $\begin{array}{c}0.027 \\
(0.006)^{* *}\end{array}$ & $\begin{array}{c}0.028 \\
(0.006)^{* *}\end{array}$ & $\begin{array}{c}0.028 \\
(0.006)^{* *}\end{array}$ & $\begin{array}{c}0.033 \\
(0.004)^{* *}\end{array}$ \\
\hline $\ln ($ state house price) & $\begin{array}{c}0.016 \\
(0.032)\end{array}$ & $\begin{array}{c}0.049 \\
(0.029)\end{array}$ & $\begin{array}{c}0.001 \\
(0.036)\end{array}$ & $\begin{array}{c}0.048 \\
(0.029)\end{array}$ & $\begin{array}{c}0.054 \\
(0.029)\end{array}$ & $\begin{array}{c}0.087 \\
(0.026)^{* *}\end{array}$ \\
\hline state unemployment & $\begin{array}{c}0.600 \\
(0.430)\end{array}$ & $\begin{array}{c}0.139 \\
(0.359)\end{array}$ & $\begin{array}{c}0.548 \\
(0.421)\end{array}$ & $\begin{array}{c}0.143 \\
(0.365)\end{array}$ & $\begin{array}{c}0.093 \\
(0.354)\end{array}$ & $\begin{array}{c}0.381 \\
(0.431)\end{array}$ \\
\hline state gov't spending & $\begin{array}{l}-0.052 \\
(0.414) \\
\end{array}$ & $\begin{array}{l}-0.167 \\
(0.465)\end{array}$ & $\begin{array}{c}0.003 \\
(0.432) \\
\end{array}$ & $\begin{array}{l}-0.164 \\
(0.463) \\
\end{array}$ & $\begin{array}{l}-0.185 \\
(0.469) \\
\end{array}$ & $\begin{array}{l}-0.559 \\
(0.366) \\
\end{array}$ \\
\hline $\begin{array}{l}\text { Transitory price } \\
\text { elasticity } \\
\text { Transitory income } \\
\text { elasticity }\end{array}$ & $\begin{array}{c}-0.469 \\
(0.043)^{* *} \\
0.251 \\
(0.017)^{* *}\end{array}$ & $\begin{array}{c}-0.520 \\
(0.053)^{* *} \\
0.298 \\
(0.009)^{* *}\end{array}$ & $\begin{array}{c}-0.474 \\
(0.050)^{* *} \\
0.195 \\
(0.037)^{* *}\end{array}$ & $\begin{array}{c}-0.538 \\
(0.055)^{* *} \\
0.294 \\
(0.009)^{* *}\end{array}$ & & \\
\hline Observations & 294,513 & 294,513 & 294,513 & 294,513 & 294,513 & 412,128 \\
\hline $\begin{array}{l}\text { Unique taxpaying } \\
\text { units }\end{array}$ & 59,621 & 59,621 & 59,621 & 59,621 & 59,621 & 59,623 \\
\hline
\end{tabular}


Table 3 -- Explaining log charitable giving by income class: controlling for fixed effects, quadratic time trend, and stock prices but not year dummies; using predictable tax change instruments and 2-year lead changes in price and income

\begin{tabular}{|c|c|c|c|c|}
\hline & (1) & (2) & (3) & (4) \\
\hline & $\begin{array}{l}\text { Income } \\
\text { less than } \\
\$ 200 \mathrm{~K}\end{array}$ & $\begin{array}{c}\text { Income } \\
\$ 200 K \& \\
\text { above }\end{array}$ & $\begin{array}{c}\text { Income } \\
\$ 500 K \& \\
\text { above }\end{array}$ & $\begin{array}{c}\text { Income } \\
\$ 1 \mathrm{M} \& \\
\text { above }\end{array}$ \\
\hline$\Delta \ln P_{t-1}$ & $\begin{array}{c}0.083 \\
(0.046)\end{array}$ & $\begin{array}{l}0.003 \\
(0.059)\end{array}$ & $\begin{array}{c}0.074 \\
(0.062)\end{array}$ & $\begin{array}{c}0.168 \\
(0.068)^{*}\end{array}$ \\
\hline$\Delta \ln P_{t}$ & $\begin{array}{c}0.198 \\
(0.088)^{*}\end{array}$ & $\begin{array}{c}0.135 \\
(0.061)^{*}\end{array}$ & $\begin{array}{c}0.191 \\
(0.064)^{* *}\end{array}$ & $\begin{array}{c}0.334 \\
(0.064)^{* *}\end{array}$ \\
\hline $\begin{array}{l}\text { InPt [persistent } \\
\text { price elasticity] }\end{array}$ & $\begin{array}{l}-0.147 \\
(0.330)\end{array}$ & $\begin{array}{c}-0.654 \\
(0.195)^{* *}\end{array}$ & $\begin{array}{c}-0.483 \\
(0.213)^{*}\end{array}$ & $\begin{array}{l}-0.493 \\
(0.276)\end{array}$ \\
\hline$\Delta \ln P_{\text {future }}$ & $\begin{array}{c}0.551 \\
(0.298)\end{array}$ & $\begin{array}{c}0.070 \\
(0.221)\end{array}$ & $\begin{array}{c}0.438 \\
(0.217)^{*}\end{array}$ & $\begin{array}{c}0.757 \\
(0.296)^{*}\end{array}$ \\
\hline$\Delta \ln Y_{t-1}$ & $\begin{array}{c}-0.057 \\
(0.013)^{* *}\end{array}$ & $\begin{array}{c}-0.054 \\
(0.007)^{* *}\end{array}$ & $\begin{array}{c}-0.057 \\
(0.008)^{* *}\end{array}$ & $\begin{array}{c}-0.060 \\
(0.009)^{* *}\end{array}$ \\
\hline$\Delta \ln Y_{t}$ & $\begin{array}{c}-0.119 \\
(0.021)^{* *}\end{array}$ & $\begin{array}{c}-0.126 \\
(0.008)^{* *}\end{array}$ & $\begin{array}{c}-0.134 \\
(0.009)^{* *}\end{array}$ & $\begin{array}{c}-0.140 \\
(0.011)^{* *}\end{array}$ \\
\hline $\begin{array}{l}\ln Y_{t} \text { [persistent } \\
\text { income elasticity] }\end{array}$ & $\begin{array}{c}0.104 \\
(0.283)\end{array}$ & $\begin{array}{c}0.783 \\
(0.115)^{* *}\end{array}$ & $\begin{array}{c}0.608 \\
(0.097)^{* *}\end{array}$ & $\begin{array}{c}0.557 \\
(0.104)^{* *}\end{array}$ \\
\hline$\Delta \ln Y_{\text {future }}$ & $\begin{array}{l}-0.324 \\
(0.312)\end{array}$ & $\begin{array}{c}0.386 \\
(0.126)^{* *}\end{array}$ & $\begin{array}{c}0.173 \\
(0.101)\end{array}$ & $\begin{array}{c}0.096 \\
(0.109)\end{array}$ \\
\hline Transitory price elasticity & $\begin{array}{c}-0.500 \\
(0.052)^{* *}\end{array}$ & $\begin{array}{c}-0.589 \\
(0.076)^{* *}\end{array}$ & $\begin{array}{c}-0.730 \\
(0.080)^{* *}\end{array}$ & $\begin{array}{c}-0.916 \\
(0.080)^{* *}\end{array}$ \\
\hline $\begin{array}{l}\text { Transitory income } \\
\text { elasticity }\end{array}$ & $\begin{array}{c}0.310 \\
(0.033)^{* *} \\
\end{array}$ & $\begin{array}{c}0.271 \\
(0.015)^{* *} \\
\end{array}$ & $\begin{array}{c}0.301 \\
(0.012)^{* *} \\
\end{array}$ & $\begin{array}{c}0.320 \\
(0.014)^{* *}\end{array}$ \\
\hline Observations & 114,901 & 179,612 & 134,838 & 93,028 \\
\hline Unique taxpaying units & 25,113 & 34,508 & 25,973 & 18,351 \\
\hline
\end{tabular}

All columns control for individual fixed effects, a quadratic time trend, log real S\&P 500 index, InP_salestax, (age/100) squared, children, other dependents, In(state house price), state unemployment rate, and state gov't spending. Robust standard errors, clustered by state and income class, are shown in parentheses.

${ }^{*}$ significant at $5 \%$;* significant at $1 \%$. 
Table 4 -- Explaining log charitable giving by income class: controlling for fixed effects and common time effects across income classes; using predictable tax change instruments and 2-year lead changes in price and income

\begin{tabular}{lcccc}
\hline & $(1)$ & $(2)$ & $(3)$ & $(4)$ \\
\hline & Income & Income & Income & Income \\
& less than & $\$ 200 \mathrm{~K} \&$ & $\$ 500 \mathrm{~K} \&$ & $\$ 1 \mathrm{M} \&$ \\
& $\$ 200 \mathrm{~K}$ & above & above & above \\
\hline \multirow{2}{*}{$\Delta \ln P_{t-1}$} & -0.003 & 0.050 & 0.121 & 0.182 \\
& $(0.075)$ & $(0.068)$ & $(0.070)$ & $(0.082)^{*}$ \\
$\Delta \ln P_{t}$ & 0.125 & 0.267 & 0.350 & 0.481 \\
$\ln P_{t}[p e r s i s t e n t$ & $(0.126)$ & $(0.078)^{* *}$ & $(0.076)^{* *}$ & $(0.085)^{* *}$ \\
price elasticity] & -0.699 & -0.772 & -0.832 & -1.079 \\
$\Delta \ln P_{\text {future }}$ & $(0.200)^{* *}$ & $(0.264)^{* *}$ & $(0.282)^{* *}$ & $(0.320)^{* *}$ \\
& 0.087 & -0.059 & 0.046 & 0.088 \\
$\Delta \ln Y_{t-1}$ & $(0.319)$ & $(0.262)$ & $(0.275)$ & $(0.335)$ \\
& -0.060 & -0.059 & -0.064 & -0.069 \\
$\Delta \ln Y_{t}$ & $(0.014)^{* *}$ & $(0.006)^{* *}$ & $(0.007)^{* *}$ & $(0.009)^{* *}$ \\
$\ln Y_{t}[p e r s i s t e n t$ & -0.103 & -0.135 & -0.145 & -0.151 \\
income elasticity] & $(0.020)^{* *}$ & $(0.008)^{* *}$ & $(0.007)^{* *}$ & $(0.009)^{* *}$ \\
$\Delta \ln Y_{\text {future }}$ & 0.846 & 0.806 & 0.699 & 0.659 \\
& $(0.155)^{* *}$ & $(0.146)^{* *}$ & $(0.145)^{* *}$ & $(0.162)^{* *}$ \\
Transitory price elasticity & 0.560 & 0.398 & 0.257 & 0.190 \\
Transitory income & $(0.165)^{* *}$ & $(0.165)^{*}$ & $(0.159)$ & $(0.173)$ \\
elasticity & -0.661 & -0.446 & -0.528 & -0.686 \\
Observations & 0.183 & 0.272 & 0.297 & 0.318 \\
Unique taxpaying units & $(0.027)^{* *}$ & $(0.018)^{* *}$ & $(0.016)^{* *}$ & $(0.015)^{* *}$ \\
\hline
\end{tabular}

All columns control for a common time effect across income classes, as well as individual fixed effects, $\ln P \_s a l e s t a x,(a g e / 100)$ squared, children, other dependents, In(state house price), state unemployment rate, and state gov't spending. Robust standard errors, clustered by state and income class, in parentheses.

${ }^{*}$ significant at $5 \%$; ${ }^{* *}$ significant at $1 \%$ 
Table 5 -- Explaining log charitable giving by income class: controlling for fixed effects and heterogeneous time effects across income classes; using predictable tax change instruments and 2-year lead changes in price and income

\begin{tabular}{|c|c|c|c|}
\hline & $(1)$ & $(2)$ & (3) \\
\hline & Income & Income & Income \\
\hline & $\begin{array}{c}\$ 200 K \& \\
\text { above }\end{array}$ & $\begin{array}{c}\$ 500 \mathrm{~K} \& \\
\text { above }\end{array}$ & $\begin{array}{l}\$ 1 M \& \\
\text { above }\end{array}$ \\
\hline \multirow{2}{*}{$\Delta \ln P_{t-1}$} & 0.104 & 0.195 & 0.260 \\
\hline & $(0.062)$ & $(0.061)^{* *}$ & $(0.069)^{* *}$ \\
\hline \multirow{2}{*}{$\Delta \ln P_{t}$} & 0.348 & 0.443 & 0.568 \\
\hline & $(0.073)^{* *}$ & $(0.080)^{* *}$ & $(0.090)^{* *}$ \\
\hline \multirow{2}{*}{$\begin{array}{l}\text { InPt [persistent } \\
\text { price elasticity] }\end{array}$} & -1.157 & -1.126 & -1.315 \\
\hline & $(0.433)^{* *}$ & $(0.587)$ & $(0.798)$ \\
\hline \multirow{2}{*}{$\Delta \ln P_{\text {future }}$} & -0.353 & -0.155 & -0.065 \\
\hline & $(0.403)$ & $(0.518)$ & $(0.719)$ \\
\hline \multirow{2}{*}{$\Delta \ln Y_{t-1}$} & -0.057 & -0.062 & -0.067 \\
\hline & $(0.007)^{* *}$ & $(0.008)^{* *}$ & $(0.010)^{* *}$ \\
\hline \multirow{2}{*}{$\Delta \ln Y_{t}$} & -0.132 & -0.144 & -0.149 \\
\hline & $(0.008)^{* *}$ & $(0.008)^{* *}$ & $(0.009)^{* *}$ \\
\hline \multirow{2}{*}{$\begin{array}{l}\ln Y_{t} \text { [persistent } \\
\text { income elasticity] }\end{array}$} & 0.777 & 0.579 & 0.544 \\
\hline & $(0.169)^{* *}$ & $(0.146)^{* *}$ & $(0.149)^{* *}$ \\
\hline \multirow{2}{*}{$\Delta \ln Y_{\text {future }}$} & 0.373 & 0.128 & 0.070 \\
\hline & $(0.189)^{*}$ & $(0.157)$ & $(0.156)$ \\
\hline \multirow{2}{*}{ Transitory price elasticity } & -0.456 & -0.528 & -0.683 \\
\hline & $(0.066)^{* *}$ & $(0.084)^{* *}$ & $(0.083)^{* *}$ \\
\hline \multirow{2}{*}{ Transitory income elasticity } & 0.271 & 0.306 & 0.326 \\
\hline & $(0.020)^{* *}$ & $(0.015)^{* *}$ & $(0.015)^{* *}$ \\
\hline Observations & 179,612 & 134,838 & 93,028 \\
\hline Unique taxpaying units & 34,508 & 25,973 & 18,351 \\
\hline
\end{tabular}

All columns control for individual fixed effects, year dummies InP_salestax, (age/100) squared, children, other dependents, In(state house price), state unemployment rate, and state gov't spending. Estimates for incomes less than $\$ 200,000$ are omitted due to weak identification. Robust standard errors, clustered by state and income class, in parentheses.

${ }^{*}$ significant at $5 \%$; ${ }^{* *}$ significant at $1 \%$ 
Table 6 -- Explaining log charitable giving: effects of alternative measures of charitable giving; using 2-year lead changes in price and income

\begin{tabular}{|c|c|c|c|c|}
\hline & (1) & (2) & (3) & (4) \\
\hline & $\begin{array}{c}\text { Current } \\
\text { donation } \\
\text { using } \\
\text { carryovers } \\
\text { from next } 2 \\
\text { years, } \\
\text { predictable tax } \\
\text { change } \\
\text { instruments }\end{array}$ & $\begin{array}{c}\text { Current } \\
\text { charitable } \\
\text { deduction, } \\
\text { predictable } \\
\text { tax change } \\
\text { instruments }\end{array}$ & $\begin{array}{c}\text { Donations using } \\
\text { carryovers from } \\
\text { next } 2 \text { years, } \\
\text { sample limited to } \\
\text { returns with next } \\
5 \text { years of data, } \\
\text { assuming perfect } \\
\text { foresight }\end{array}$ & $\begin{array}{l}\text { Current donation } \\
\text { using carryovers } \\
\text { from next } 5 \\
\text { years, sample } \\
\text { limited to returns } \\
\text { with next } 5 \text { years } \\
\text { of data, } \\
\text { assuming perfect } \\
\text { foresight }\end{array}$ \\
\hline$\Delta \ln P_{t-1}$ & $\begin{array}{l}-0.015 \\
(0.049)\end{array}$ & $\begin{array}{l}-0.074 \\
(0.034)^{*}\end{array}$ & $\begin{array}{c}0.020 \\
(0.041)\end{array}$ & $\begin{array}{l}0.026 \\
(0.041)\end{array}$ \\
\hline$\Delta \ln P_{t}$ & $\begin{array}{c}0.155 \\
(0.058)^{* *}\end{array}$ & $\begin{array}{l}-0.026 \\
(0.045)\end{array}$ & $\begin{array}{c}0.251 \\
(0.070)^{* *}\end{array}$ & $\begin{array}{c}0.249 \\
(0.068)^{* *}\end{array}$ \\
\hline $\begin{array}{l}\ln P_{t} \text { [persistent } \\
\text { price elasticity] }\end{array}$ & $\begin{array}{c}-0.707 \\
(0.254)^{* *}\end{array}$ & $\begin{array}{c}-0.681 \\
(0.195)^{* *}\end{array}$ & $\begin{array}{c}-0.753 \\
(0.085)^{* *}\end{array}$ & $\begin{array}{c}-0.738 \\
(0.086)^{* *}\end{array}$ \\
\hline$\Delta \ln P_{\text {future }}$ & $\begin{array}{l}-0.083 \\
(0.266)\end{array}$ & $\begin{array}{c}0.022 \\
(0.214)\end{array}$ & $\begin{array}{c}0.140 \\
(0.055)^{*}\end{array}$ & $\begin{array}{c}0.149 \\
(0.059)^{*}\end{array}$ \\
\hline$\Delta \ln Y_{t-1}$ & $\begin{array}{c}-0.059 \\
(0.007)^{* *}\end{array}$ & $\begin{array}{c}-0.052 \\
(0.004)^{* *}\end{array}$ & $\begin{array}{c}-0.048 \\
(0.009)^{* *}\end{array}$ & $\begin{array}{c}-0.047 \\
(0.009)^{* *}\end{array}$ \\
\hline$\Delta \ln Y_{t}$ & $\begin{array}{c}-0.128 \\
(0.006)^{* *}\end{array}$ & $\begin{array}{c}-0.085 \\
(0.006)^{* *}\end{array}$ & $\begin{array}{c}-0.120 \\
(0.012)^{* *}\end{array}$ & $\begin{array}{c}-0.121 \\
(0.013)^{* *}\end{array}$ \\
\hline $\begin{array}{l}\ln Y_{t} \text { [persistent } \\
\text { income elasticity] }\end{array}$ & $\begin{array}{c}0.906 \\
(0.164)^{* *}\end{array}$ & $\begin{array}{c}1.033 \\
(0.149)^{* *}\end{array}$ & $\begin{array}{c}0.407 \\
(0.023)^{* *}\end{array}$ & $\begin{array}{c}0.402 \\
(0.023)^{* *}\end{array}$ \\
\hline$\Delta \ln Y_{\text {future }}$ & $\begin{array}{c}0.527 \\
(0.179)^{* *}\end{array}$ & $\begin{array}{c}0.716 \\
(0.164)^{* *}\end{array}$ & $\begin{array}{c}0.020 \\
(0.010) \\
\end{array}$ & $\begin{array}{c}0.019 \\
(0.010) \\
\end{array}$ \\
\hline $\begin{array}{l}\text { Transitory price } \\
\text { elasticity }\end{array}$ & $\begin{array}{c}-0.469 \\
(0.043)^{* *}\end{array}$ & $\begin{array}{c}-0.730 \\
(0.063)^{* *}\end{array}$ & $\begin{array}{c}-0.642 \\
(0.081)^{* *}\end{array}$ & $\begin{array}{c}-0.639 \\
(0.080)^{* *}\end{array}$ \\
\hline $\begin{array}{l}\text { Transitory income } \\
\text { elasticity }\end{array}$ & $\begin{array}{c}0.251 \\
(0.017)^{* *}\end{array}$ & $\begin{array}{c}0.232 \\
(0.016)^{* *}\end{array}$ & $\begin{array}{c}0.266 \\
(0.011)^{* *}\end{array}$ & $\begin{array}{c}0.262 \\
(0.011)^{* *}\end{array}$ \\
\hline Observations & 294,513 & 294,513 & 106,494 & 106,494 \\
\hline $\begin{array}{l}\text { Unique taxpaying } \\
\text { units }\end{array}$ & 59,621 & 59,621 & 29,063 & 29,063 \\
\hline
\end{tabular}

All columns control for individual fixed effects, year dummies, $\ln P \_s a l e s t a x$, (age/100) squared, children, other dependents, In(state house price), state unemployment rate, and state gov't spending. Robust standard errors, with clustering by state and income class, in parentheses.

${ }^{*}$ significant at $5 \%$; ${ }^{* *}$ significant at $1 \%$. 
Table 7 -- Explaining log charitable giving: pooled cross section estimates

\begin{tabular}{|c|c|c|c|c|}
\hline & (1) & (2) & (3) & (4) \\
\hline & $\begin{array}{c}\text { All } \\
\text { incomes }\end{array}$ & $\begin{array}{c}\text { All } \\
\text { incomes }\end{array}$ & $\begin{array}{l}\text { Income } \\
\text { less than } \\
\$ 200 \mathrm{~K}\end{array}$ & $\begin{array}{c}\text { Income } \\
\$ 200 K \& \\
\text { above }\end{array}$ \\
\hline $\ln P_{t}$ & $\begin{array}{c}-0.816 \\
(0.129)^{* *}\end{array}$ & $\begin{array}{c}-0.808 \\
(0.106)^{* *}\end{array}$ & $\begin{array}{c}-0.477 \\
(0.112)^{* *}\end{array}$ & $\begin{array}{c}-1.287 \\
(0.185)^{* *}\end{array}$ \\
\hline $\ln Y_{t}$ & $\begin{array}{c}0.827 \\
(0.018)^{* *}\end{array}$ & $\begin{array}{c}0.831 \\
(0.016)^{* *}\end{array}$ & $\begin{array}{c}0.659 \\
(0.026)^{* *}\end{array}$ & $\begin{array}{c}0.829 \\
(0.021)^{* *}\end{array}$ \\
\hline age & $\begin{array}{c}0.027 \\
(0.004)^{* *}\end{array}$ & $\begin{array}{c}0.027 \\
(0.004)^{* *}\end{array}$ & $\begin{array}{c}0.026 \\
(0.004)^{* *}\end{array}$ & $\begin{array}{c}0.046 \\
(0.006)^{* *}\end{array}$ \\
\hline (age/100) squared & $\begin{array}{c}0.334 \\
(0.345)\end{array}$ & $\begin{array}{c}0.301 \\
(0.360)\end{array}$ & $\begin{array}{l}-0.078 \\
(0.374)\end{array}$ & $\begin{array}{l}-1.077 \\
(0.577)\end{array}$ \\
\hline married & $\begin{array}{c}0.229 \\
(0.024)^{* *}\end{array}$ & $\begin{array}{c}0.223 \\
(0.023)^{* *}\end{array}$ & $\begin{array}{c}0.133 \\
(0.026)^{* *}\end{array}$ & $\begin{array}{c}0.325 \\
(0.032)^{* *}\end{array}$ \\
\hline children & $\begin{array}{c}0.122 \\
(0.007)^{* *}\end{array}$ & $\begin{array}{c}0.119 \\
(0.007)^{* *}\end{array}$ & $\begin{array}{c}0.116 \\
(0.010)^{* *}\end{array}$ & $\begin{array}{c}0.123 \\
(0.010)^{* *}\end{array}$ \\
\hline other dependents & $\begin{array}{c}0.107 \\
(0.006)^{* *}\end{array}$ & $\begin{array}{c}0.107 \\
(0.006)^{* *}\end{array}$ & $\begin{array}{c}0.093 \\
(0.008)^{* *}\end{array}$ & $\begin{array}{c}0.120 \\
(0.008)^{* *}\end{array}$ \\
\hline InP_salestax & & $\begin{array}{l}-1.123 \\
(0.982)\end{array}$ & $\begin{array}{l}-2.108 \\
(1.121)\end{array}$ & $\begin{array}{l}-0.541 \\
(1.187)\end{array}$ \\
\hline In(state house price) & & $\begin{array}{l}-0.028 \\
(0.058)\end{array}$ & $\begin{array}{c}0.187 \\
(0.058)^{* *}\end{array}$ & $\begin{array}{c}-0.215 \\
(0.077)^{* *}\end{array}$ \\
\hline state unemployment & & $\begin{array}{l}-1.104 \\
(0.799)\end{array}$ & $\begin{array}{c}0.903 \\
(0.861)\end{array}$ & $\begin{array}{c}-2.804 \\
(1.124)^{*}\end{array}$ \\
\hline church & & $\begin{array}{c}0.865 \\
(0.253)^{* *}\end{array}$ & $\begin{array}{c}1.348 \\
(0.268)^{* *}\end{array}$ & $\begin{array}{c}0.486 \\
(0.366)\end{array}$ \\
\hline state gov't spending & & $\begin{array}{c}2.038 \\
(0.869)^{*} \\
\end{array}$ & $\begin{array}{c}1.469 \\
(0.997) \\
\end{array}$ & $\begin{array}{c}2.199 \\
(1.062)^{*}\end{array}$ \\
\hline Observations & 412,132 & 412,132 & 160,241 & 215,771 \\
\hline
\end{tabular}

All columns control for year dummies (not shown). Robust standard errors, clustered by state and income class, in parentheses. ${ }^{*}$ significant at $5 \%$; ${ }^{* *}$ significant at $1 \%$ 


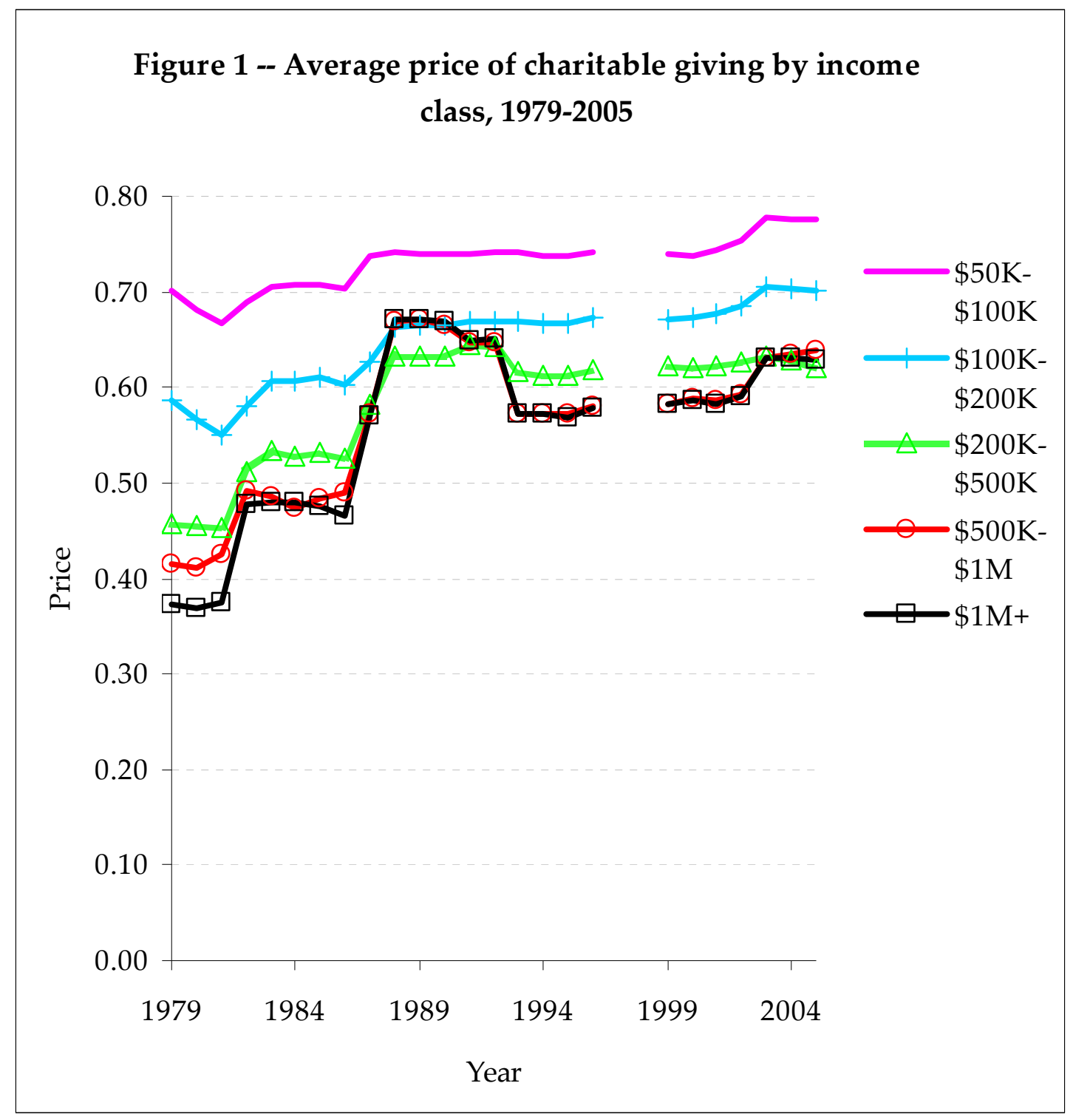

Graph depicts the "first dollar" price (calculated setting charity to zero), constructed as described in the text. Sample includes taxpayers who are in the panel data as exogenous itemizers without change in marital status for at least 6 consecutive years, and whose itemized deductions less charity exceed the largest standard deduction or zero bracket amount during the sample period in real terms. Taxpayers are classified into income categories based on current income in constant year 2007 dollars, replacing realized capital gains with $6 \%$ of capitalized dividends. 


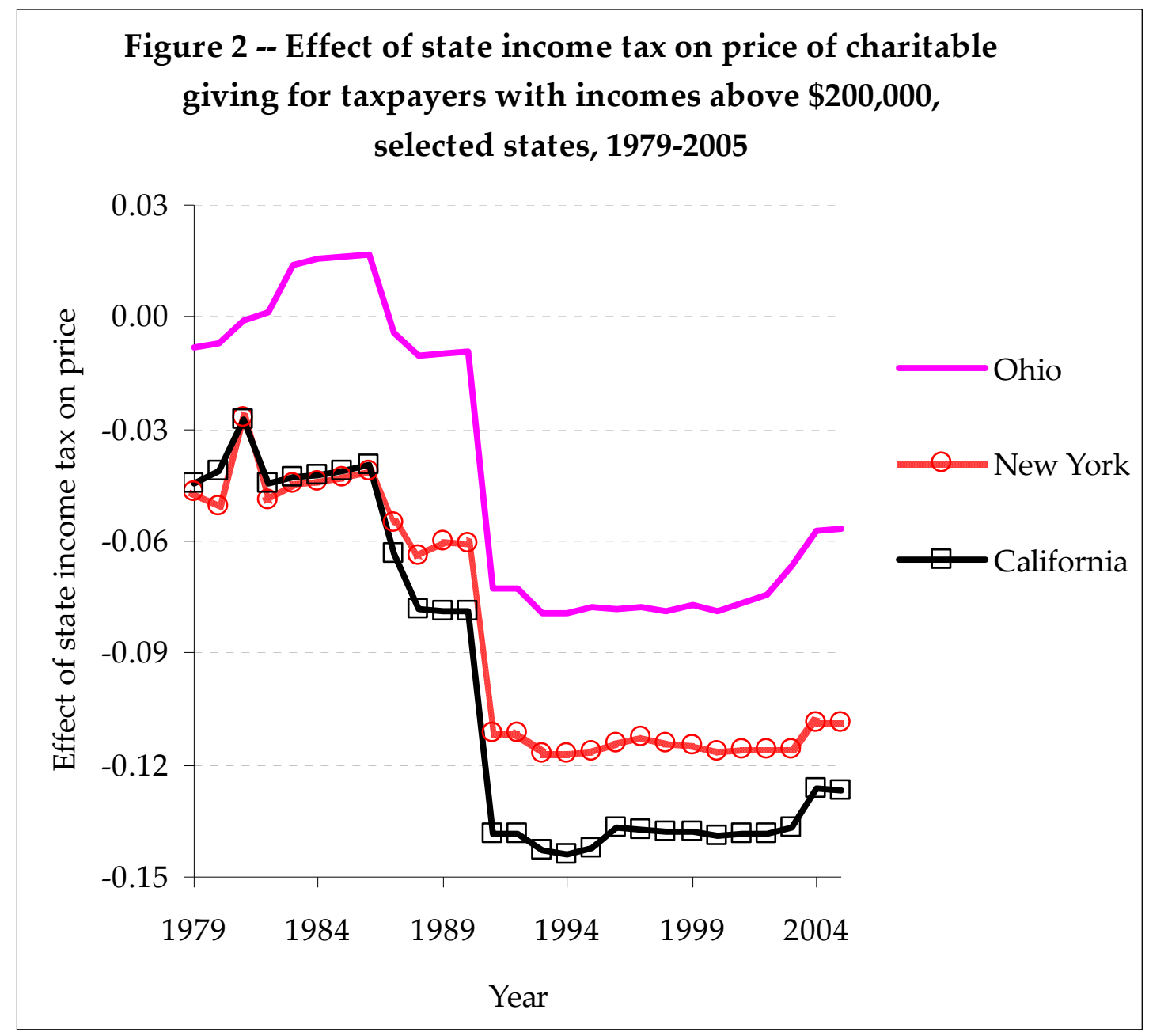

Graph depicts the price of charitable giving, minus the price that would apply in the absence of a state income tax. Prices are weighted averages of individual-level prices calculated on a random sample of taxpayers with incomes above $\$ 200,000$ (in 2007 dollars) from the 1985 SOI public-use cross section, where the weights make the proportion of taxpayers in each income class similar to the proportion in the sample we use for econometric estimation. The same set of taxpayers are used to calculate tax rates for each state, and their characteristics except for state taxes are held constant in real terms across states and years. 


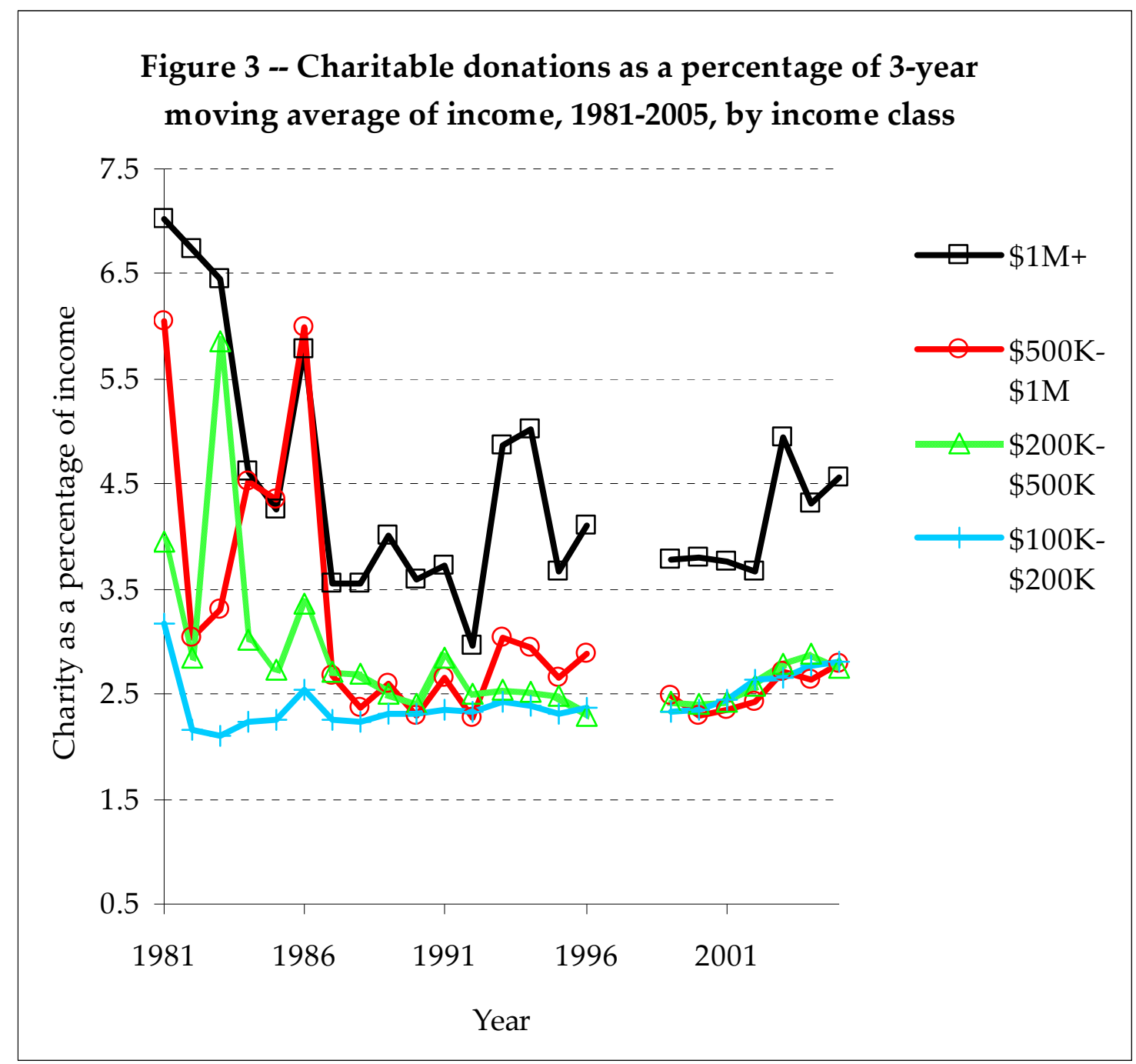

Sample used to construct Figure 3 includes taxpayers who are in the panel data as exogenous itemizers without change in marital status for at least 6 consecutive years, and whose itemized deductions less charity exceed the largest standard deduction or zero bracket amounts during the sample period in real terms. Uses a moving average of current and up to two lags of income when available, in constant year 2007 dollars, replacing realized capital gains with $6 \%$ of capitalized dividends. 


\section{References}

Auten, Gerald, and Janette Wilson. 1999. "Sales of Capital Assets Reported on Individual Tax Returns, 1985." Statistics of Income Bulletin 18 (Spring), pp. 355-88.

Auten, Gerald, James Cilke, and William Randolph. 1992. "The Effects of Tax Reform on Charitable Contributions." National Tax Journal. 45 (3), 267-290.

Auten, Gerald, Holger Sieg, and Charles Clotfelter. 2002. "The Distribution of Charitable Giving, Income and Taxes: An Analysis of Panel Data." American Economic Review, Vol. 92, No. 1 (March), 371-382.

Bakija, Jon. 2000. “Distinguishing Transitory and Permanent Price Elasticities of Charitable Giving with Pre-Announced Changes in Tax Law." Working Paper, Williams College. <http://www.williams.edu/Economics/wp/bakijacharity.pdf>

Bakija, Jon. 2008. “Documentation for a Comprehensive Historical U.S. Federal and State Income Tax Calculator Program" Working paper, Williams College. $<$ http://www.williams.edu/Economics/papers/bakijaDocumentation_IncTaxCalc. pdf $>$

Bakija, Jon, and Rob McClelland. 2004. “Timing vs. Long-run Charitable Giving Behavior: Reconciling Divergent Approaches and Estimates." Working Paper.

Barrett, Kevin S., Anya M. McGuirk, and Richard Steinberg. 1997. "Further Evidence on the Dynamic Impact of Taxes on Charitable Giving." National Tax Journal. 50 (2), 321-334.

Bertrand, Marianne, Esther Duflo, and Sendhil Mullainathan. 2004. "How Much Should We Trust Differences-in-Differences Estimates?" Quarterly Journal of Economics, Vol. 119, No. 1 (February), pp. 249-75

Bogart, William T., and William M. Gentry. 1995. "Capital Gains Taxes and Realizations: Evidence from Interstate Comparisons." Review of Economics and Statistics, v77, n2 (May): 267-82.

Broman, Amy J. 1989. "Statutory Tax Rate Reform and Charitable Contributions: Evidence from a Recent Period of Reform." Journal of the American Taxation Association. (Fall), 7-21.

Brown, Eleanor. 1997. "Taxes and Charitable Giving: Is There a New Conventional Wisdom?" Proceedings of the Eighty-Ninth Annual Conference on Taxation held under the auspices of the National Tax Association, November 10-12, 1996. pp. 153-59 
Burman, Leonard E., William G. Gale, and Jeffrey Rohaly. 2003. "The Expanding Reach of the Individual Alternative Minimum Tax." Journal of Economic Perspectives, Spring 2003, v. 17, iss. 2, pp. 173-86.

Burman, Leonard E., Kimberly A. Clausing, and John F. O'Hare. 1994. "Tax Reform and Realizations of Capital Gains in 1986." National Tax Journal. Vol. 47 No. 1 (March), pp. 1-18.

Burman, Leonard E. and William C. Randolph. 1994. "Measuring Permanent Responses to Capital Gains Tax Changes in Panel Data." American Economic Review, v. 84, No. 4 (September), pp. 794-809.

Center on Philanthropy at Indiana University. 2007. Giving USA 2007. Glennview, IL: Giving USA Foundation.

Chetty, Raj, Adam Looney, and Kory Kroft. 2007. "Salience and Taxation: Theory and Evidence." NBER Working Paper No. 13330 (August).

Cilke, James, Julie-Anne Cronin, Matthew Eichner, Janet McCubbin, James R. Nunns, and Paul Smith. (1999). "Developing a Panel Model for Tax Analysis." Unpublished manuscript prepared for the 92nd Annual Conference on Taxation, National Tax Association.

Clotfelter, Charles T. 1985. Federal Tax Policy and Charitable Giving. Chicago: University of Chicago Press.

Feenberg, D. 1987. "Are Tax Price Models Really Identified: The Case of Charitable Giving." National Tax Journal. 40 (4), 629-633.

Feldstein, Martin S. and Clotfelter, Charles T. “Tax Incentives and Charitable Contributions in the United States: A Microeconometric Analysis." Journal of Public Economics, January- February 1976, 5(1-2), pp. 1-26.

Feldstein, Martin. "The Income Tax and Charitable Contributions: Part I -- Aggregate and Distributional Effects." National Tax Journal 28 (March 1975): 81-100

Friedman, Milton. 1957. A Theory of the Consumption Function. Princeton, N.J.: Princeton University Press.

Goolsbee, Austan. 2000. “What Happens When You Tax the Rich? Evidence from Executive Compensation." Journal of Political Economy. Vol. 108, No. 2.

Ikovic, Zoran, James Poterba, and Scott Weisbenner. 2005. "Tax-Motivated Trading by Individual Investors." American Economic Review. Vol. 95 (Dec.) pp. 1605-1630. 
Karlan, Dean and John List. 2007. "Does Price Matter in Charitable Giving? Evidence From a Large-Scale Natural Field Experiment." American Economic Review. Vol. 97, No. 5 (December), pp. 1774-93.

OFHEO (Office of Federal Housing Enterprise Oversight). 2006. 3 ${ }^{\text {rd }}$ Quarter 2006 Manipulatable Data for Individual State Index $<$ http://www.ofheo.gov/download.asp>.

Peloza, John and Piers Steele. (2005), "The Price Elasticities of Charitable Contributions: A Meta Analysis." Journal of Public Policy E Marketing 24(2): 260-272.

Poterba, James M., and Scott Weisbenner. 2001. “The Distributional Burden of Taxing Estates and Unrealized Capital Gains at Death." In Rethinking Estate and Gift Taxation, edited by William G. Gale, James R. Hines Jr., and Joel Slemrod (pp. 422-449). Washington, DC: Brookings Institution Press.

President's Advisory Panel on Federal Tax Reform. 2005. "Simple, Fair, and ProGrowth: Proposals to Fix America's Tax System." Washington: GPO.

Randolph, W.C. 1995. "Dynamic Income, Progressive Taxes, and the Timing of Charitable Contributions." Journal of Political Economy. 103 (4), 709-738.

Saez, Emmanuel. 2004. “The Optimal Treatment of Tax Expenditures.” Journal of Public Economics, Vol. 88, pp. 2657-2684.

San Diego Union-Tribune. 2006. "Church or Synagogue Attendance by State.” May 6. <http://www.signonsandiego.com/uniontrib/20060502/news_lz1n2thelist.html>.

Schaffer, M.E., 2007. "xtivreg2: Stata module to perform extended IV/2SLS, GMM and AC/HAC, LIML and k-class regression for panel data models." $<$ http://ideas.repec.org/c/boc/bocode/s456501.html>.

U.S. Bureau of the Census. 2004. Historical Census of Housing Tables. $<$ http://www.census.gov/hhes/www/housing/census/historic/values.html>.

Weber, Michael and Victoria L. Bryant. (2005). “The 1999 Individual Income Tax Return Edited Panel." in 2005 Proceedings of the American Statistical Association. Alexandria, VA: American Statistical Association. 


\section{APPENDICES}

\section{Appendix 1: Derivation of the discount factor applied to the effective capital gains rate used to construct our price variables}

As explained in the text, we specify the price of charitable giving as $P_{i t}=1-m t r_{i t}-$ $n_{i t}{ }^{*} a^{*}\left(d^{*} m\right.$ trcg $_{i t+1}-m$ trcharcg $\left._{i t}\right)$. Recall that $n$ is non-cash donations as a share of total donations, $a$ is unrealized appreciation as a share of non-cash donations, and $d$ is a discount factor applied to the capital gains tax rate to reflect the fact that the alternative to donating an appreciated asset today may be to realize the capital gain on the asset at some distant future date or not at all.

There is relatively little evidence available to determine a reasonable value for the discount factor $d$ applied to the capital gains rate. The previous literature has generally ignored mtrcharcg, and has assumed that the product $a^{*} d=0.5$. The 0.5 comes from papers by Feldstein (1975) and Feldstein and Clotfelter (1976) that estimated it as a parameter in a cross-sectional charitable giving equation using maximum likelihood methods. If we were to follow this rule of thumb, a value of $a=0.65$ would imply $d=0.77$. We attempt to improve on this, or at least corroborate the reasonableness of the prior rule of thumb, by inferring a reasonable value for $d$ based on recent research by Ivkovic, Poterba, and Weisbenner (2005). Based on five years of individual-level data on asset trades from a brokerage house, they estimate the probability of selling an asset at each point over the five year period, conditional on the accumulated capital gains. Using this in conjunction with an assumed statutory tax rate on realized capital gains of $28 \%$ and an assumed 1\% monthly nominal rate of appreciation (which is roughly consistent with the experience of the S\&P500 1979-2005), they estimate an effective present-valueequivalent marginal tax rate on gains of $24 \%$ if assets not sold in the first 5 years are sold in year 5, 13\% if assets not sold in the first 5 years are sold in year 20, and $0.6 \%$ if assets not sold in the first 5 years are held until death 20 years in the future. We compute an effective rate on assets sold at any time over 20 years by linearly interpolating between the $24 \%$ and $13 \%$ rates, assuming probabilities of sale in 5 -year 
periods from year 5 to year 20 are proportional to sales of assets with that holding period as a share of total sales of assets with holding periods between 5 and 20 years, reported in Auten and Wilson (1999). We then compute the weighted average of that and the $0.6 \%$ rate on gains held until death in 20 years, where the weight on $0.6 \%$ is the estimated revenues that would be raised form taxing unrealized gains at death in 1998 (estimated by Poterba and Weisbenner, 2003) divided by actual revenues raised from taxing capital gains, from <http://www.treas.gov/offices/tax-policy/library/capgain22008.pdf>. The resulting effective rate is $19.5 \%$, implying a discount factor of $19.5 / 28$ or approximately 0.7 .

\section{Appendix 2: Details and sources for control variables}

To construct $\ln$ (state house price), we start with the median house price each state from 2000 decennial census, and grow it forwards and backwards by state-specific OFHEO repeat-sales housing price index, and then deflate it using the national CPI-U. See U.S. Bureau of the Census (2004) and OFHEO (2006). State unemployment rate is from the U.S. Bureau of Labor Statistics website $<$ http://www.bls.gov $>$. The church variable is the share of state residents who say they "attend church or synagogue once a week or almost every week," from a Gallup poll cited in San Diego Union-Tribune (2006). State

gov't spending is direct current expenditures of state and local governments as a share of state personal income, obtained from the Urban-Brookings Tax Policy Center State and Local Government Finances database. The state retail sales tax rate is taken from the University of Michigan's World Tax Database, updated by the authors through 2005 using Research Institute of America's All States Tax Handbook, various years.

\section{Appendix 3: Details on the construction of the dependent variable, current charitable contributions.}

In our data, we have the amount of prior year contribution that is carried over and claimed in the current year for all observations in all years from 1980 on. The year in which the carryover was originally donated is not reported in the data. Moreover, 
taxpayers do not report directly whether their contributions were limited in a particular year, and the percent of AGI limits differ depending on the type of organization to which the taxpayer is contributing and the type of gift. To address these problems, we use the following algorithm to attempt to identify the year in which carryover contributions originated.

For any taxpayer that reports carried over contributions from prior years in year $t$, we look back to year $t$ - 1 . If no carryovers were claimed, then year $t-1$ is considered a possible source of the carryover. We then check year $t-2$. If year $t-1$ was not a possible source, and no carryovers were claimed in year $t-2$, then year $t-2$ is considered a possible source of the carryover. If year $t-1$ was a possible source, then we include $t-2$ as also a possible source only if no carryover was claimed in year $t-2$ and the taxpayer was likely to be limited under the rules that pertain to "not-50\% organizations" (for which the percent of AGI limits are lower). If more than one year is identified as a possible source, we then attempt to refine the set of possible source years by including as possible sources only the years that would have been limited under limits that apply to " $50 \%$ organizations" (for which the percent of AGI limits are higher). The vast majority of charitable contributions are to $50 \%$ organizations. Finally, we allocate the carryover amounts equally among the year or years that are identified as possible sources of the carryover. The re-allocated carryovers are then added to the charitable deduction for the year or years when we deem the original donation to have occurred, and we subtract from that total the carryovers that were claimed in that year but came from prior year donations.

Our tax return data include the amounts that taxpayers originally reported on the individual line items from Schedule A for non-cash donations (except for a subset of returns in 1979 and 1980), and in some years and for some samples we also have the individual line item from Schedule A for cash donations. Taxpayers sometimes report amounts on these line items that are clearly in excess of the applicable percentage of AGI limits, and then apply the limits only on the line item for the final charitable deduction. However, an alternative approach of constructing current donations from the sum of the 
line items for cash and non-cash donations reported on Schedule A would be an unreliable indicator of current donations. The instructions for how to apply the percentage of AGI limits on charitable giving are contained in IRS Publication 526 (versions of this publication dating back to 1992 are available at www.irs.gov). In many years since 1992, the relevant worksheet in that publication specifically instructed taxpayers to report the after-limitation amounts of non-cash donations and cash donations on the individual line items for those types of donations on Schedule A. In other years, the worksheet was ambiguous in this regard. Moreover, the IRS Statistics of Income division edited the cash, non-cash, and carryover line item variables in 19871990 to make them sum to the allowable charitable deduction. In any event, using this alternative approach would dramatically shrink our sample size and remove many years with tax reforms that are useful for identification, because the amount reported on the individual line item for cash donations on Schedule A is only available in our data for a limited number of years.

\section{Appendix 4: First stage regressions and tests for weak instruments}

This appendix presents further details on the "predictable tax change instrument" approach, and considers whether "weak instruments" are likely to be a problem. This is indeed a legitimate concern, as this identification strategy is very demanding. In particular, it is challenging to separately identify the effects of expected future changes in price from expected future changes in income. As we have emphasized, the identification in our instruments for these comes from predictable changes in nearfuture taxation. But tax reforms are such that predictable future changes in marginal tax rates and predictable future changes in tax liabilities often go hand-in-hand.

Nonetheless, there is still useful independent variation between the two. For instance, some federal tax changes, such as those in 2001 and 2003, were intended both to reduce marginal rates and tax liabilities, while others, such as TRA86, were specifically designed to reduce marginal rates while holding tax liabilities roughly constant over time for each income class. In addition, some state income taxes do not allow a 
deduction for charity, so that changes in those taxes mainly affect after-tax income and not price, whereas other states do allow deductions for charity, in which case changes affect both price and after-tax income.

To check for "weak instruments," we perform the Anderson canonical correlation test and the Cragg-Donald weak identification test for all equations that use instrumental variables. Every regression reported in the paper passes these tests (rejecting the null hypothesis of weak identification) with a p-value that rounds to 0.0000 .

Appendix Tables A.1 and A.2 provide some further information on how our predictable tax change instrument approach works. In table A.1, we report estimates from the regressions that we run to construct the predicted values of future income that are in turn run through the tax calculator to help us construct the predictable tax change instruments for future changes in price and income. The most striking pattern evident from this table is strong empirical confirmation of mean-reversion in income. That is, positive lagged changes in income and high current levels of income both strongly predict a future decline in income.

Appendix Table A.2 displays the coefficients on the excluded instruments for one example specification, the "predictable tax change instrument" approach using $t+2$ leads that was shown in column (1) of Table 2. The excluded instrument most closely associated with each endogenous (or measured-with-error) explanatory variable is highlighted in gray. Not surprisingly, the instruments for lagged changes in log price and the current level of log price have high partial correlations with their endogenous counterparts from the second stage equation, as they are just first-dollar versions of those variables. The more difficult identification challenge arises with the future changes in price and income. In the first stage regression for $\Delta \ln P_{f u t u r e}$ in column (4) of Table A.2, the coefficient on the exogenous instrument for $\Delta \ln P_{\text {future }}$ is 0.130 with a standard error of 0.018 ; i.e., a one percent increase in the predictable component of future $\log$ price is associated with a 0.13 percent increase in actual future log price. In column (5), the coefficient on the instrument for $\Delta \ln Y_{\text {future }}$ is 0.122 with a standard error of 
0.017. That the instruments are highly statistically significant is reassuring. Not surprisingly, given the existence of large unpredictable fluctuations in pre-tax income over time, the instruments seem to explain a relatively small portion of future changes in price and income. The capital gains tax rate instruments help somewhat in this regard. For instance, in column (5), a one percentage point increase in the future capital gains tax rate, holding the current rate constant, is estimated to lead to a future decline in income of 0.105 percent, with a standard error of 0.049 . This makes sense; if next year's capital gains rate is predicted to be higher than this year's rate, then people would tend to realize more income this year and less income next year, hence the decline in future income. In column (4), the coefficient on future change in capital gains marginal tax rate also makes sense; if next year's marginal tax rate on capital gains is higher than today's, more income gets realized today relative to next year, which pushes taxpayers into a higher tax bracket today and a lower tax bracket next year (hence, the increase in price next year).

The bottom line is that although our instruments for the future price and income changes do not explain a huge portion of the rather noisy actual future changes in price and income, they have sensible signs and are highly statistically significant, and the identification is strong enough to avoid weak instruments bias. The fact that they explain a relatively small portion of the variation in future price and income changes is borne out by the low values of the Shea partial R-squared's for the future price and income changes. But here we are helped greatly by the fact that weak instruments bias is a small-sample bias problem -- i.e., it is a function of both the partial R-squared of the excluded instruments and the size of the sample, and we are using an enormous sample. Thus, we strongly reject the null hypothesis of weak instruments bias. As discussed in the text, the specifications in some of our ensuing sensitivity analyses do exhibit symptoms of weak identification in the sense of a high degree of multicollinearity and large standard errors, despite passing the weak instruments test, so caution must be exercised in interpreting those results. 
Appendix Table A.1 -- Regressions to predict future changes in log pre-tax income, used to help construct predictable tax change instruments

\begin{tabular}{lcc}
\hline & $\begin{array}{c}\text { Change in log pre-tax } \\
\text { income over the next one } \\
\text { year }\end{array}$ & $\begin{array}{c}\text { Change in log pre-tax } \\
\text { income over the next } \\
\text { two years }\end{array}$ \\
\hline In(pre-tax income $)_{t-1}$ & -0.095 & -0.121 \\
& $(0.001)^{* *}$ & $(0.002)^{* *}$ \\
Aln(pre-tax income $)_{t}$ & -0.286 & -0.336 \\
& $(0.002)^{* *}$ & $(0.002)^{* *}$ \\
In(pre-tax income $)_{t}$ & -0.041 & -0.056 \\
age & $(0.001)^{* *}$ & $(0.001)^{* *}$ \\
& -0.002 & -0.005 \\
(age/100) squared & $(0.000)^{* *}$ & $(0.001)^{* *}$ \\
children & 0.127 & 0.316 \\
& $(0.041)^{* *}$ & $(0.054)^{* *}$ \\
other dependents & 0.019 & 0.026 \\
& $(0.001)^{* *}$ & $(0.001)^{* *}$ \\
state unemployment & 0.003 & 0.008 \\
married & $(0.001)^{* *}$ & $(0.001)^{* *}$ \\
Constant & 0.270 & 0.988 \\
& $(0.055)^{* *}$ & $(0.070)^{* *}$ \\
Observations & 0.027 & 0.037 \\
R-squared & $(0.003)^{* *}$ & $(0.003)^{* *}$ \\
\hline Standard er* & 0.495 & 0.720 \\
& $(0.014)^{* *}$ & $(0.018)^{* *}$ \\
\hline 359,000 & 294,833 \\
& 0.11 & 0.12 \\
\hline & &
\end{tabular}

Standard errors in parentheses.

${ }^{*}$ significant at $5 \%$; ${ }^{* *}$ significant at $1 \%$ 
Appendix Table A.2 -- Coefficients on excluded instruments in first stage regressions for specification in Table 2, column (1)

\begin{tabular}{|c|c|c|c|c|c|}
\hline & (1) & (2) & (3) & (4) & (5) \\
\hline & $\Delta \ln P_{t-1}$ & $\Delta \ln P_{t}$ & $\ln P_{t}$ & $\Delta \ln P_{\text {future }}$ & $\Delta \ln Y_{\text {future }}$ \\
\hline$\Delta \ln P_{t-1}, 1$ st-dollar & $\begin{array}{c}0.779 \\
(0.011)^{* *}\end{array}$ & $\begin{array}{c}0.018 \\
(0.003)^{* *}\end{array}$ & $\begin{array}{l}-0.004 \\
(0.003)\end{array}$ & $\begin{array}{c}0.041 \\
(0.005)^{* *}\end{array}$ & $\begin{array}{c}0.119 \\
(0.015)^{* *}\end{array}$ \\
\hline$\Delta \ln P_{t}, 1$ st-dollar & $\begin{array}{c}0.101 \\
(0.006)^{* *}\end{array}$ & $\begin{array}{c}0.774 \\
(0.013)^{* *}\end{array}$ & $\begin{array}{c}-0.031 \\
(0.005)^{* *}\end{array}$ & $\begin{array}{c}0.078 \\
(0.007)^{* *}\end{array}$ & $\begin{array}{c}0.191 \\
(0.022)^{* *}\end{array}$ \\
\hline $\ln P_{t}, 1$ st-dollar & $\begin{array}{l}-0.010 \\
(0.006)\end{array}$ & $\begin{array}{c}-0.058 \\
(0.008)^{* *}\end{array}$ & $\begin{array}{c}0.868 \\
(0.016)^{* *}\end{array}$ & $\begin{array}{c}-0.658 \\
(0.011)^{* *}\end{array}$ & $\begin{array}{c}-0.305 \\
(0.034)^{* *}\end{array}$ \\
\hline $\begin{array}{l}\text { Predictable tax change } \\
\text { instrument for } \Delta \ln P_{\text {future }}\end{array}$ & $\begin{array}{c}0.018 \\
(0.004)^{* *}\end{array}$ & $\begin{array}{c}0.050 \\
(0.005)^{* *}\end{array}$ & $\begin{array}{c}0.062 \\
(0.006)^{* *}\end{array}$ & $\begin{array}{c}0.130 \\
(0.018)^{* *}\end{array}$ & $\begin{array}{c}0.071 \\
(0.032)^{*}\end{array}$ \\
\hline $\begin{array}{l}\text { Predictable tax change } \\
\text { instrument for } \Delta \ln Y_{\text {future }}\end{array}$ & $\begin{array}{c}0.005 \\
(0.002)^{*}\end{array}$ & $\begin{array}{c}-0.009 \\
(0.003)^{* *}\end{array}$ & $\begin{array}{c}0.007 \\
(0.002)^{* *}\end{array}$ & $\begin{array}{c}0.040 \\
(0.004)^{* *}\end{array}$ & $\begin{array}{c}0.122 \\
(0.017)^{* *}\end{array}$ \\
\hline $\begin{array}{l}\text { MTR on capital gains, year } \\
t, 1 \text { st-dollar }\end{array}$ & $\begin{array}{l}-0.027 \\
(0.011)^{*}\end{array}$ & $\begin{array}{c}0.010 \\
(0.020)\end{array}$ & $\begin{array}{l}-0.011 \\
(0.024)\end{array}$ & $\begin{array}{c}0.252 \\
(0.027)^{* *}\end{array}$ & $\begin{array}{l}-0.408 \\
(0.069)^{* *}\end{array}$ \\
\hline $\begin{array}{l}\text { Expected change in MTR on } \\
\text { capital gains at } t+1\end{array}$ & $\begin{array}{c}0.038 \\
(0.010)^{* *}\end{array}$ & $\begin{array}{c}0.072 \\
(0.012)^{* *}\end{array}$ & $\begin{array}{c}0.070 \\
(0.011)^{* *}\end{array}$ & $\begin{array}{c}0.076 \\
(0.019)^{* *}\end{array}$ & $\begin{array}{c}-0.105 \\
(0.049)^{*}\end{array}$ \\
\hline Observations & 294,513 & 294,513 & 294,513 & 294,513 & 294,513 \\
\hline Unique taxpaying units & 59,621 & 59,621 & 59,621 & 59,621 & 59,621 \\
\hline $\begin{array}{l}\text { Partial R-squared of } \\
\text { excluded instruments }\end{array}$ & 0.4284 & 0.4051 & 0.5287 & 0.2397 & 0.0044 \\
\hline Shea partial R-squared & 0.4274 & 0.4442 & 0.0627 & 0.0166 & 0.0026 \\
\hline $\begin{array}{l}\text { P-value of F-test on } \\
\text { excluded instruments }\end{array}$ & 0.0000 & 0.0000 & 0.0000 & 0.0000 & 0.0000 \\
\hline
\end{tabular}

All columns also control for individual fixed effects, year dummies, $\ln P \_$salestax, (age/100) squared, children, other dependents, In(state house price), state unemployment rate, and state gov't spending. Robust standard errors, clustered by state and income class, are reported in parentheses.

* significant at $5 \%$;* significant at $1 \%$. 